\title{
VESSELS OF TRANSFER: Allegories of Afrofuturism in Jeff Mills and Janelle Monáe
}

FeAture Article

\author{
TOBIAS C. VAN VEEN \\ MCGILL UNIVERSITY
}

\begin{abstract}
The performances, music, and subjectivities of Detroit techno producer Jeff Mills-radio turntablist The Wizard, space-and-time traveller The Messenger, founding member of Detroit techno outfit Underground Resistance and head of Axis Records-and Janelle Monáe-android \#57821, Cindi Mayweather, denizen and "cyber slavegirl" of Metropolis_are infused with the black Atlantic imaginary of Afrofuturism. We might understand Mills and Monáe as disseminating, in the words of Paul Gilroy, an Afrofuturist "cultural broadcast" that feeds "a new metaphysics of blackness" enacted "within the underground, alternative, public spaces constituted around an expressive culture ... dominated by music" (Gilroy 1993: 83). Yet what precisely is meant by "blackness" - the black Atlantic of Gilroy's Afrodiasporic cultural network-in a context that is Afrofuturist? At stake is the role of allegory and its infrastructure: does Afrofuturism, and its incarnates, "represent" blackness? Or does it tend toward an unhinging of allegory, in which the coordinates of blackness, but also those of linear temporality and terrestial subjectivity, are transformed through becoming?
\end{abstract}

KEYWORDS: Afrofuturism, Afrodiaspora, becoming, identity, representation, race, android, alien, Detroit techno, Janelle Monáe

TOBIAS C. VAN VEEN is a writer, sound-artist, technology arts curator and turntablist. Since 1993 he has organised interventions, publications, gatherings, exhibitions and broadcasts around technoculture, working with MUTEK, STEIM, Eyebeam, the New Forms Festival, CiTR, Kunstradio and as Concept Engineer and founder of the UpgradeMTL at the Society for Arts and Technology (SAT). His writing has appeared in many publications. Tobias is editor of the forthcoming volume Other Planes of There: Afrofuturism Collected. As of 2014 tobias will be Postdoctoral Researcher in Communication at the Université de Montréal. An archive of DJ mixes resides at djtobias.com.

Dancecult: Journal of Electronic Dance Music Culture 5(2): 7-41

ISSN 1947-5403 @2013 Dancecult http://dj.dancecult.net

DOI 10.12801/1947-5403.2013.05.02.02

dsincecult 


\section{ALL things exist, live and react in relation to space.}

—jazz vocalist King Pleasure, liner notes to Golden Days (1960)

I wanted to land a UFO on the track.

-Model 500

Again that's the reason for the masks, we were simple "vessels of transfer" from somewhere beyond our understanding which I think people understood and could see.

—Mad Mike Banks, Underground Resistance ${ }^{1}$

The performances, music and subjectivities of Jeff Mills and Janelle Monáe are infused with the black Atlantic imaginary of Afrofuturism. Mills, a founding member of Detroit techno outfit Underground Resistance, innovative turntablist and pioneer of minimalist techno production, has performed worldwide since the early 1990s; Monáe, in her guise as android Cindi Mayweather-and with the blessings of Prince and Big Boi of Outkast ${ }^{2}$ - has risen to become the heir apparent to a futurist and freaky Afropop tradition.

Their respective global reach demonstrates Paul Gilroy's observation that the black Atlantic-Gilroy's term for the "non-traditional tradition, an irreducibly modern, excentric, unstable, and asymmetrical cultural ensemble" of the Afrodiaspora (1993: 198) communicates and establishes shared identities and nodal points of history through calland-response forms of music even as its subjects are "separated in space and time or divided by the technologies of sound reproduction and the commodity form" (indeed since the development of the internet, such "imaginary effects" of dispersed identification and history are all the more powerful; see Gilroy 1993: 102). We might understand Mills and Monáe as continuing the black Atlantic ex-centric tradition by disseminating an Afrofuturist "cultural broadcast" that feeds "a new metaphysics of blackness" that becomes enacted "within the underground, alternative, public spaces constituted around an expressive culture... dominated by music" (Gilroy 1993: 83). Yet what precisely is meant by "blackness" in a context which is Afrofuturist? In which Monáe's Cindi Mayweather is an android on the run from human authorities, and in which Mills has become the Messenger, a time-andspace traveller returning from the future to forewarn us of the catastrophic results of first contact with extraterrestrials?

Such "identities" - which I here adopt as fluid and performative — often lend themselves to a movement that exceeds their characterization as stage personae, suggesting a becoming that transforms the coordinates of subjectivity. ${ }^{3}$ Thus we need ask whether such identitiesAfrofuturist androids, aliens, cyborgs, etc.- "represent", in an allegorical mode, conditions of Afrodiasporic experience ("blackness") or whether Afrofuturism is capable of unhinging allegorical referents to humanist bodies and terrestrial markers of difference, thereby developing autonomous forms of becoming and thought: rather than a "a new metaphysics 
of blackness", do we not encounter a "MythScience" that challenges our previously held conceptions of blackness and of metaphysics?

\section{Prelude I. The Messenger}

JEFF MILLS is crouched over his equipment: his fingers gracefully flying over the DJ mixer, silver headphones cocked on his head, his intense gaze taking in the five glowing Pioneer CD decks that surround him in a semi-circle. A heavy black cloth drapes the stage like a ceremonial shroud. Mills is a lone figure on stage, intense and focused, as if manning a solo soundship, the navigator of a relentless barrage of intergalactic techno (see fig. 1). The outer space symbolism of Mills' multimedia composition is not accidental: the sights and sounds of Afrofuturism pervade the haunting, minimalist performance. A science fictional array of bleeps, squelches and synthesizers crack audibly like solar flares, punctuating the intensive polyrhythms and driving bass; behind Mills, a photograph of Earth's moon fills the massive projection screen (see fig. 2 below).

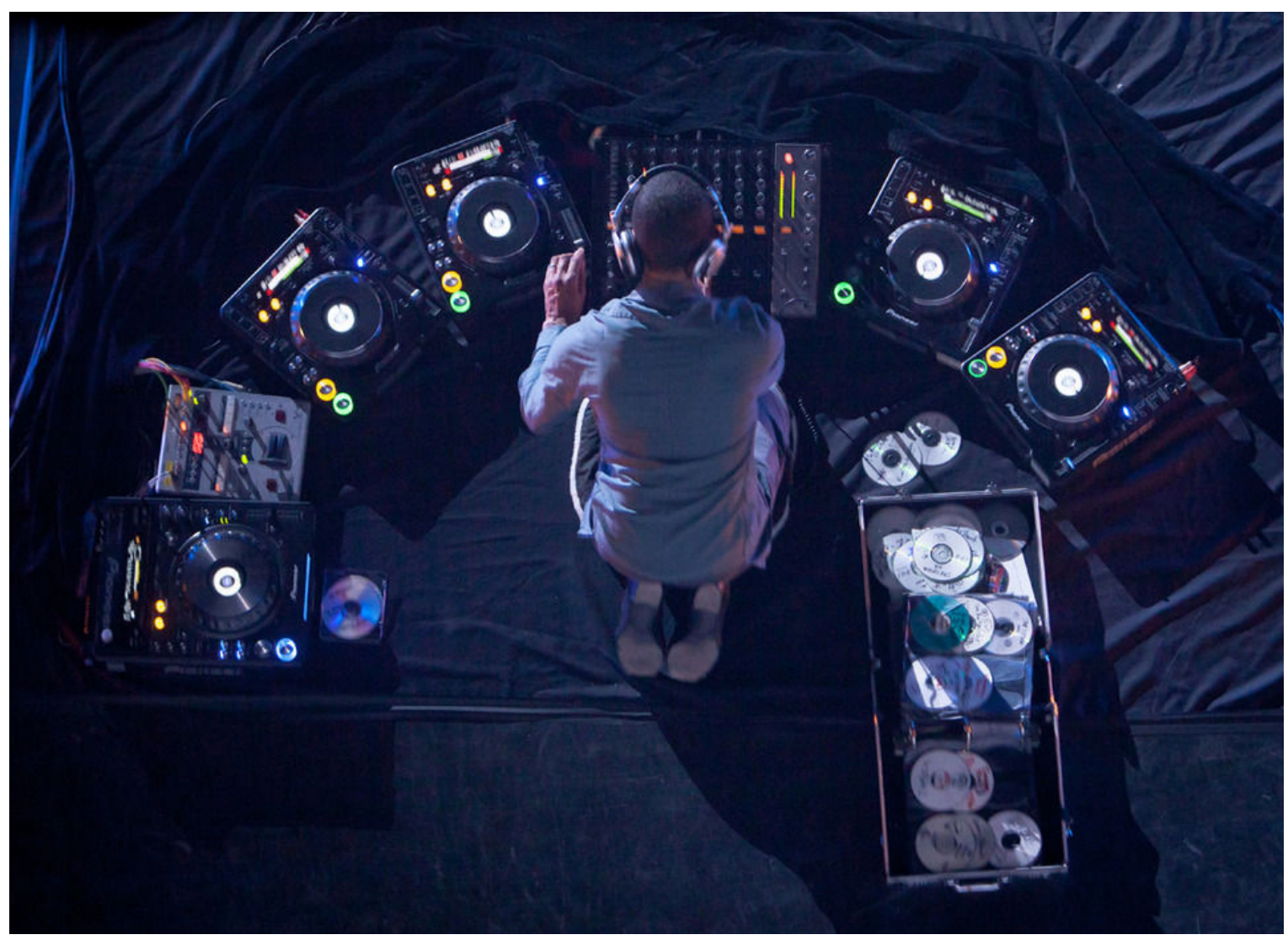

Figure 1. Jeff Mills at MUteK 2012, Montréal. Photo: Mutek.org. 
Among the scattered scenes of planetary electronic dance music culture (EDMC), Mills' performance is emblematic of Afrofuturism-a term more complex than it first appears, Afrofuturism delineates a tradition of Afrodiasporic media production, thought and performance that engages science fictional practices and themes to envision alternate identities, timelines and counterrealities. Such envisioning operations create startling, creative and uncanny effects - often, by imaginatively challenging whitewashed futures and colonialist histories with Africentric and futurist revisionings-while crucially offering ways to subversively transform Afrodiasporic subjectivities.

Afrofuturism invokes multiple strategies. On one level, its narratological and fictive operations seeks to represent black subjects in futurist timelines. On other levels, it utilises alternate timelines and other worlds as allegories capable of representing but also transforming the coordinates of the present-such as becoming alien or android subjectivities that challenge the meaning of "race" in post-humanist timelines. ${ }^{5}$

Afrofuturism also provides a framework for deciphering its "MythSciences" and "AlterDestinies". Its reflexivity produces its own tools of interpretation. As Nabeel Zuberi writes, Afrofuturism "codifies, organises and maps an alternative cultural history and critical framework for [Afrodiasporic] media production" (2004: 79). ${ }^{6}$ This includes the entry of Afrofuturism into scholarship, where since the early 1990s a nascent field of "Afrofuturist studies" has begun to appear in a number of disparate publications, undertaking genealogies of Afrofuturist motifs in literature, film, music, and other media. ${ }^{7}$

The development and imaginative embrace of alien, machinic, astral, and cyborg subjectivities in Afrofuturism, all of which abandon or modify the archetypal, Enlightenment form of the human - from Janelle Monáe's ArchAndroid to Jeff Mills' Messenger-offer an escape hatch from paradigms for Afrodiasporic identity that are all too often restricted to the violence and capitalist bling of ghetto realism, confined to post-slavery resonances of subalternity, or entrapped within the lingering effects of the Civil Rights era, in which African-American subjects had to struggle, over the course of a long century since the Emancipation Proclamation, for the right to be considered Enlightenment subjects. To this end, as Kodwo Eshun argues, "It's in music that you get the sense that most AfricanAmericans owe nothing to the status of the human. African-Americans still had to protest, still had to riot, to be judged Enlightenment humans in the 1960s" (1999: A[193]). Hence the transformative capacity of the alien, and of Afrofuturist science fictional approaches, that explore unEarthly universes, timelines, and identities. When the "human" is nothing but the historical entitlement of white supremacy, signifying an embodied technology of exclusion, there is little reason to invest within the very same paradigm that was once deployed to systemically oppress and enslave one's ancestors. ${ }^{8}$

Even at the outset, with its aliens and androids, Afrofuturism is full of unbelievable figures and outright paradoxes. This is not surprising, given the mythical status-and extensive mythical systems - of its practitioners, from Sun Ra, the ancient alien Pharoah from Saturn, jazz composer, philosopher poet, and Arkestra bandleader, whose music novelist Anthony Joseph alluded to as "transcendent jazz - the metaphysics of another world" (2006: 120), 
to Dr. Octagon, the alien gynecologist and hip-hop emcee of "robot voodoo power" from Jupiter;" from George Clinton's Dr. Funkenstein and the Mothership Connection of space funk outfit Parliament, to Detroit techno outfit Underground Resistance and their collective of black resistance fighters (the Suburban Knight, Chamaleon, Chaos, Mad Mike, Rolando), and underwater Drexciyans (descendents of slaves thrown overboard during the Middle Passage).

Afrofuturism confronts the participant with these mythical figures that nonetheless "walk the Earth". Such fantastical becomings-what Sun Ra called the "Living Myth" of his own impossibility - confront the scholar with a choice, or rather, upset the divide in Western thought between myth and science, fact and fiction, the real and the imaginary. In the close to his interview "Motion Capture" in More Brilliant Than The Sun (1999), Kodwo Eshun argues that either one begins by accepting the interesting effects of the impossibility, for example, that Sun Ra was born on Saturn, and is the return (from the future) of an ancient alien deity who once ruled Kemet-the Afrocentrist name for the revisionist history/myth of black Pharoahnic Egypt—or one dismisses Ra's extravagance as merely fiction, his thought as merely poetic, his jazz as merely music, his entire strategy here on Earth as merely that of an intriguing but irreverent artist, who nonetheless isn't as "serious" or "politically effective" compared to his fellow travellers of the era, such as Malcolm X, the Nation of Islam, or the Black Panthers. To bow to the latter dismissal, which would eschew all that strays from the gravity of the supposedly serious path of outright political action, however, is to leave the greatest fiction of all-consensual reality and its imperial history-unquestioned. It is also to ignore the equally fantastical elements of the Black Panthers (who housed Sun Ra when he taught at Berkeley in 1971; see Kreiss 2008), and the Yacub/Mother Plane mythotheology of the Nation of Islam. ${ }^{10}$ To sidestep the tricky dynamics by which myth informs reality, in which fiction builds fact, is to not only enact a puritanical division that in-itself is fictive, but it is to close the door upon creative strategies of manifesting other worlds and AlterDestinies-which is to say, transformed Afrofutures, futures otherwise for us all-just as it is to leave unquestioned the reality that, apparently, we are all human-just some more human than others. It is also to decisively ignore the fact that for hundreds of years, Africanist peoples were subjected to the fiction of biological inferiority and thus, the fact of slavery. This constitutively contaminated relation between fact/fiction is known in the work of Sun Ra as MythScience.

Thus Afrofuturism challenges the invisible paradigm of unquestioned reality-the "reality" that in the past has proclaimed the inferiority of blackness and the de jure privilege of white supremacy, that has denied certain peoples the status of "human" and cast them as alien slaves, the invisibly "white" reality where blackness is alienated-through the construction of MythSciences and the intervention of chronopolitics (Eshun 2003). In what follows I will seek to provide provisional encounters with these concepts, thereby aiding in the development of a shared lexicon for Afrofuturist studies that, at the same time, complicates what are becoming a set of assumptions concerning the role of allegory in Afrofuturism. I seek to articulate these concepts-hinge them to practices, or better, demonstrate how 
such (technological) practices demonstrate the operational force of a concept (in Eshun's language, conceptechnics) - by way of an immersion in two contemporary Afrofuturists, both of whom engage with electronic music and are deeply invested in dance cultures: the techno releases and DJ performances of Jeff Mills; and the android Afrofunk of Janelle Monáe. But first I begin with allegory.

\section{Allegories of Afrofuturism}

As Afrofuturist Kodwo Eshun explains, in a passage that picks up on several themes that will occupy us below,

It's in music that you get this sense that most African-Americans owe nothing to the status of the human. African-Americans still had to protest, still had to riot, to be judged Enlightenment humans in the 1960s-it's quite incredible. And in music, if you listen to guys like Sun Ra-I call them despots, Ra, Rammellzee, and Mad Mike [of Underground Resistance] - part of the whole thing about being an AfricanAmerican alien musician, is that there's this sense of the human as being a really pointless and treacherous category, a category which has never meant anything to African-Americans. This is particularly true with Sun Ra-just because Ra pushes it by saying that he comes from Saturn. I always accept the impossibility of this. I always start with that, where most people would try and claim it was an allegory. But it isn't an allegory: he really did come from Saturn. I try to exaggerate this impossibility ... (Eshun 1998: A[193]).

Eshun performs a double-move that at once demonstrates the inadequacy and yet the necessity of reading Afrofuturism as allegory-precisely because he does the latter himself.

On the one channel, Eshun advocates an approach to Afrofuturism that urges us to embrace Afrofuturism's impossible claims of alien embodiment, thereby unhinging the figure of the alien from being nothing other than an allegory of the historical experience of slavery, structural racism and persistent discrimination. This crucial move allows us to think through Afrofuturism's temporal effects-how it challenges the reality of certain histories, and the history of certain realities - and thus to conceptualize its discourse as autonomous. There is no need, once allegory is unhinged, to continuously read Afrofuturism as "standing in for a reality elsewhere". Yet, even as Eshun refuses the allegorical role of Sun Ra's alien identity, for example, he nonetheless derives the Afrofuturist critique of the human from the historical experiences of African-Americans.

On the other channel, Eshun refuses the allegorical role of Sun Ra precisely because we can understand him as saying that African-American experience remains, in reality, an unhuman condition: thus "African-Americans still had to protest, still had to riot, to be judged Enlightenment humans in the 1960s". The reality of this fiction-that AfricanAmericans are unhuman-is the constitutive paradox at work, for now it is the historical conditions themselves that are already irreal, as it were, and as they remain, wherever the "real fiction" of racist formations take place. It is that racist fictions become realities, and 
thus inscribe real histories, with real laws and real effects, that shapes the constitutive and intractable paradox at work in considering the role of "allegory" in Afrofuturism: for what allegory is there for the fiction of racism, for experience lived as inhuman, when it is already a fiction? Thus the standard definition of allegory-as a fiction that represents the real, a literalization technique that symbolizes a referent, be it a concept, thing, event, or personis upset. In Afrofuturism, allegory itself is the epistemological condition of possibility for the real/fiction divide. Afrofuturism itself arises from a set of historical conditions-the trauma of slavery, that in Public Enemy's phrase, "Armageddon bin in effect" (1988), but also through a shared set of non-Western belief systems and occult beliefs-that question the supposed impermeability between reality and fiction, precisely from irreal conditions. I will explicate this below with Janelle Monáe.

\section{Definitions of Afrofuturism Unearthed: New Forms of the Other}

SPEAKING on CBC Radio's Q with Jian Ghomeshi, Monáe strikes a cool, if not unsettling, poise, as if she remains undecided whether she is appearing as Monáe or as her alien-android alter-ego, Cindi Mayweather. With the release of The Electric Lady in 2013, Monáe has arrived at the forefront of what might be called Afropop-a fusion of soul, funk, hip-hop and $\mathrm{R} \& \mathrm{~B}$ that references Prince, Betty Wright, James Brown, George Clinton, Michael Jackson, and Grace Jones (among others) just as it resonates with Afrofuturist motifs of the android, time travel, and outer space. Her five-part Metropolis Suite, now in its second album (with one extended EP), undertakes an imaginative reinterpretation of Fritz Lang's 1927 silent film, Metropolis. Crucial to this reinterpretation is her inversion of Maria, the female android who is constructed to seduce and trick the proletarian workers of Metropolis. In Monáe's version, "slave cybergirl" \#57821 becomes the ArchAndroid, the revolutionary mediator between the proles and the elites, just as her Africanist embodiment reverses Maria's whiteness to the ArchAndroid's blackness. Over the course of the Suite, the ArchAndroid is on the run from the authorities, and hides-in-plain-sight, posing as the pop star Cindi Mayweather, a.k.a. The Electric Lady.

Back in CBC studios, Monáe is cool—very cool—behind the mic. As if programmed. Then she begins talking about androids:

I speak about androids because androids represent, to me, a new form of 'the other.' And I love speaking about the future because it gives us all a chance to rewrite history and do what's right - or continue to do what's wrong, and oppress those we don't understand, oppress those who may not look like us. I think it's important that those issues or subjects are still being brought to the forefront. I mean, you can parallel it all to being an immigrant in today's United States, to just being the minority in the majority. So Cindi [Mayweather, the ArchAndroid] represents the heart, the mediator between the mind and the hands (Monáe 2011).

When Janelle Monáe speaks of androids as a new form of the other, she demonstrates the allegorical force of Afrofuturism: the way in which its science fictional tropes-in 
particular its aliens and androids-are capable of representing experiences of the "other". What is the mode, however, of this representation? Monáe's "parallel" is the immigrant, but also a generalized experience of othering, in which oppression follows from visual difference, an effect of "being the minority in the majority". On stage, Monáe has often remarked before singing her anthemic "Cold War" that the song speaks to her experience as an African-American woman in the music industry. The track's second stanza is telling, in which Monáe sings, in her guise as Cindi: "If you want to be free / The underground is the only place to be". Here, the "underground" takes on a double signification, suggesting both Monáe's unconventional and conceptual-which is to say, Afrofuturist-approach to the industry, but also Cindi's flight, as she descends into the subterranean labyrinth of Metropolis. As if directed both to the droids and humans of Metropolis circa 2026 and the "oppressors" and "others" of today's Earth, the chorus repeats: "This is a cold war / do you know what you're fighting for?" Monáe's coolness and Cindi's androidal composure (the most composed, perhaps, since the 1950s bebop style of Miles Davis) can thus be explicated: her Afrofuturist mythsystem is an effect of the cold war, that ongoing, protracted struggle known as racism, to which the droid's "cold war" serves as allegory.

For the most part, scholars of Afrofuturism have embraced definitions that emphasize its allegorical force, and by which allegory is understood as a fiction representing real conditions. Mark Dery coined the broad definition of Afrofuturism in 1994 as Afrodiasporic "signification that appropriates images of technology and a prosthetically enhanced future" (136) to-as Yaszek summarizes- "explore how people of color negotiate life in a technology intensive world" (2006:42). ${ }^{11}$ Alondra Nelson, who co-founded the Afrofuturism.net listserv with Paul D. Miller in 1998, cites the definition agreed upon by list members as Afrodiasporic "voices with other stories to tell about culture, technology and things to come", as well as "sci-fi imagery, futurist themes, and technological innovation in the African diaspora" (Nelson 2002: 9). ${ }^{12}$ Nelson and Miller go on to outline the task of the Afrofuturist scholar as exploring "futurist themes in black cultural production and the ways in which technological innovation is changing the face of black art and culture" (2004). More germane to EDMC, Nabeel Zuberi describes sonic Afrofuturism as "a black music tradition that engages with separation, escape and otherness through the tropes of Science Fiction" (2004: 78). In Zuberi's definition, the historical markers of a universalized "black experience" are likewise allegorized through science fiction.

To this end, Afrofuturist scholarship has focused on science fiction produced by Afrodiasporic authors and artists, wherein the authorial body is grounded as the "real" from which the work is read as allegory. This approach lends itself to sociological accounts of Afrodiasporic engagements with technologies (see Nelson, Thuy and Hines 2001). Scholars have likewise positioned Afrofuturism as a way to redress the problematic of the "digital divide" wherein, as Nelson writes "blackness gets constructed as always oppositional to technologically driven chronicles of progress" (2002: 1). Afrofuturism thus presents an imaginative realm capable of redressing the digital divide, insofar as it gestures toward a corpus of authorial Afrodiasporic bodies involved with various technological practices, as 
well as media that allegorize blackness in technoscientific narratives. Yet important and necessary as such analyses are, they approach their limitations when facing the unhinged force of Afrofuturist allegory, and its potential to transform the parameters of its "real" referents. What if Monáe's “other" isn't just a question of mapping its meaning back onto her (African-American, female) authorial body, and of mapping the androidal cold war onto existing conditions of racism, but of thinking through, at the same time- as she saysnew forms of the other?

Monáe's alter-ego, the alien-android Cindi Mayweather, draws attention to the technologies of othering. The android, which is a robot constructed to appear as if human, is nonetheless a second-class, mechanistic, subaltern subject. The cover of Metropolis: The Chase Suite depicts Mayweather/Monáe as a half-dismembered robot, her white metallic body, replete with protruding wires and a head implant, missing an entire arm, a hand, and a lower torso. The number " 57821 " is visible on her chest, along with a circuitboard and a series of buttons. That her body is white suggests that her erstwhile blackness is a skin that has been removed, revealing the cold metallic truth of her construction. That this "truth" appears as white suggests a complicated dialectic at play between black/white, which is elsewhere reflected in her costuming, and appreciation for uniforms, from primarily black tuxedos (circa The ArchAndroid (2010)) to white (The Electric Lady (2013)). Monáe's play between white/black suggests a more complex operation at work than that of a grounded, allegorical referent to either white or black bodies. Or humans. It suggests, in the words of Paul Gilroy, an operation that makes "raciology appear anachronistic" (2004: 335). But the meaning of such an anachronism, when the future appears to recall the past, is also more complex than at first appears.

But what form might this new other take? The opening to Metropolis: The Chase Suite (2008), begins by narrating the plight of Cindi, who is on the run-from the authorities and their bounty hunters - as she has fallen in love with a human:

I'm an a-a-alien from outer space (outer space)

I'm a cybergirl without a face, a heart, or a mind

(a product of the man, I'm a product of the man)

I'm a slave girl without a race (without a race)

On the run cause they hate our ways and chase my kind

They've come to destroy me!

— Janelle Monáe, “Violet Stars Happy Hunting!” (2008)

Cindi is a product of the (hu)man: an androidal technology. "She" — as in Monáe's world, androids have genders ${ }^{13}$ - is also "slave girl without a race". If she is not categorizable by race, this is because she is not human and thus (one speculates) not subject to racial ideologies of hierarchical biologism. She is nonetheless "a new form of the other". What "other" is this, if the android does not represent—or cannot solely be reduced to-race per se? 


\section{Specters of the Atlantic: Pharoahs, Aliens and Androids}

MONÁE'S STRATEGIC DEPLOYMENT of Cindi Mayweather is successful precisely because it unearths a straightforward allegorical reading of Afrodiasporic conditions of otherness-or, as I would like to suggest, because such otherness is already an allegory. The fictive reality of the android folds back on itself, reaching an uncomfortable point where the allegory of the android to blackness, and the real experience of becoming an android, have already met in the historical trauma of slavery. The android "is a product of the man:" it has been engineered to undertake certain servile tasks-much like how African subjects were enslaved (and thus purchased, traded, and sold) as commodities.

The commodification of subjectivity is emphasized by Ian Baucom in his Specters of the Atlantic: Finance Capital, Slavery, and the Philosophy of History (2005). Baucom argues that it is because humans are already "represented" as commodities-the modernity of the "Subject \$" - that modern commodity capitalism gets its jumpstart. Baucom goes on to demonstrate that "it is to finance capital rather than to the French Revolution [as argued by Hegel] . . that we should look for the birthplace of the modern subject, the origins of a philosophical discourse on and of the modern" (Baucom 2005: 55). In short, modern subjectivity is not born in the fire of radical democracy and the overthrow of the monarchy by the bourgeoisie: it is born in the advent of slavery as the complete commodification of the subject. It is this complete commodification of the subject, argues Baucom, that is an effect of the general structure of allegory.

Baucom quotes Halpern: "The commodity renders allegory obsolete by perfecting and globalizing the latter's logic of representation. Under mature capitalism, allegory is no longer simply a literary technique but is rather the phenomenology of the entire social-material world" (Halpern 1997: 13; in Baucom 2005: 21). Allegory is thus not the "effect" of commodity capital, or to put it in crude Marxian terms, the aesthetic form of superstructure to capital's commodity base. As Baucom writes, allegory is "something closer to an epistemological condition of possibility: a mode of representation which enables and clears the grounds for a form of capital which is an intensification and a wider practice of it" (2005: 21). The commodity-the human commodity qua slave, qua android-is "practical allegory-allegory in the sphere of social practice" (Halpern, in Baucom 2005: 21). That the Afrodiasporic slave marks the birth of modernity in the commodity form is a point already made by novelist Toni Morrison, as Kodwo Eshun remarks:

In an interview with critic Paul Gilroy in his 1991 anthology Small Acts, novelist Toni Morrison argued that the African subjects that experienced capture, theft, abduction, mutilation, and slavery were the first moderns. They underwent real conditions of existential homelessness, alienation, dislocation, and dehumanization that philosophers like Nietzsche would later define as quintessentially modern. Instead of civilizing African subjects, the forced dislocation and commodification that constituted the Middle Passage meant that modernity was rendered forever suspect (Eshun 2003: 288). 
The "new form of the other", in the form of the android, the cyborg, the alien, or the posthuman in general, is thus the cyclic return of an old form that marks the birthplace of modernity: the enslaved-commodified human. That the new form of the other resurrects a past is a central motif of Afrofuturism, where its futurological operations tend to themeatize ancient Africanist MythSciences. On the cover of The ArchAndroid (2010), Janelle Monáe appears in what appears to be a gold, Pharoahnic headdress, though uncannily so as an android, the ancient Egyptian wear transformed into a technological skyline of Metropolis itself. In doing so, Monáe plays on the Afrofuturist trope of the ancient black alien or android Pharoah, as initiated by Sun Ra's playful (but altogether serious) deconstruction of Afrocentric historical revisioning, the latter exemplified in texts such as James' Stolen Legacy (2001 [1954]), and what Gilroy outlines as "popular 'afrocentric' assertions that the great discoveries of Western science and technology were known to ancient Africa, stolen from their ancient sources, and then assigned by white supremacist historians to the Greeks" (2004: 339). While there is some effective reality to be gleaned from Afrocentrism's historically revisionist claims - a debate that rages around the more careful work of Martin Bernal's Black Athena (2002) - I would suggest that when Afrocentric historical revisioning attempts to establish monolithic historical claims that support an essentialist raciology, rather than challenge it, the black political culture that results tends toward a confined, static elaboration of both race and history that forecloses the imaginative unfolding of the future, and thus, is at odds with Afrofuturism.

The coordinates of the present at stake here, as Paul Gilroy outlines, is the "Romantic and sentimental distaste for the racial capitalism that, at an earlier point, had made blacks themselves into commodities, [and that] is a profound factor that influences the moral conditions in which black political cultures take shape" (2004: 333). At stake in Afrofuturist temporal operations-what we will explicate shortly as its chronopolitics (Eshun 2003) - is a symbolic combat that challenges what Gilroy outlines as "militant vindicative [black] nationalism", and its historical revisionism that seeks to establish an essential blackness as original or superior (2004: 338-9). In this respect, the Afrofuturist appropriation of Kemetian motifs, for example in Earth, Wind, and Fire's pyramidal and Pharoahnic fantasies, or Killah Priest's pharoahnic headdress on The Psychic World of Walter Reed (2013), expands rather than contracts such mythos: it elevates it to a MythScience, in which the future reveals a past transformed, and in which blackness, and black identity, is likewise unshackled from its restraints-including the programmatic referral to "blackness" as the central marker of difference. By exploring alternate forms of becoming that unbind the confines of race, Afrofuturism implicitly affirms a "widely shared sense of race consciousness as earthbound and anachronistic" just as it explicitly pursues "another mode of recognition in the most alien identity" that carries it "beyond the human altogether" (Gilroy 2004: 344; 348-9).

\section{"ARMAGEDDON BIN IN EFFECT": ChRONOPOLITICS}

BAUCOM's underlying temporal thesis in Specters of the Atlantic (drawn from Walter Benjamin) is that of an eternal return that marks the "long contemporaneity" of capitalism, 
"the idea that oscillating forms of capital [which we here read as embodied allegories of commodified subjectivity] inform and are informed by the shifting phenomenologies and recycled generic protocols of cultural practice" (2005: 23). The effect of cyclicity as a historical form means that each cycle contains within itself the ghostly aftereffect of a past cycle, in the manner of Fredric Jameson's theory of "sedimented" genre in The Political Unconscious, whereby "the ideology of form itself, thus sedimented, persists into the later, more complex structure" (1981: 141). This also means that each cyclic sedimentation faces the uncanny return of its repressed. The point I wish to make here is that temporal cyclicity is a signature or form that Afrofuturism carries into our own future from its past. Cyclicity itself is a historical form, and there are different forms of it. Thus temporal cyclicity, the looping return and its insistent repetition, is itself an insistent occupation, or motif, of Afrofuturism that changes over time, just as each one of its cycles is haunted by a repressed/ sedimented form of the cycle-such shifts in cyclicity perhaps explaining the appeal of repetitious electronic music. ${ }^{14}$ Jeff Mills' focus on change and cyclicity in his texts and techno productions (which I will turn to below) is echoed by Monáe, who summarizes the above discussion when she says "I love speaking about the future because it gives us all a chance to rewrite history".

The effect of such cyclic temporality upon scholarship means that each Afrofuturist cycle of cyclicity, each genre of repetition, signals a form wherein "time does not pass, it accumulates" (Baucom 2005: 24). WIRE journalist Mark Sinker mapped out such a sedimented temporality in his 1992 article, "Loving the Alien", in which he suggested that the android and the alien are not just referential allegories for past or present black identity - though they also serve this contemporaneous purpose-but in Sun Ra's words, "real fictions" that demonstrate the ongoing reality of such allegory, in which the accumulation of past cycles of futurism overlay the phenomenology of the unfolding present:

The advantage of Science Fiction (Sf) as a point of cultural departure is that it allows for a series of worst-case futures-of hells-on-Earth and being in them-which are woven into every kind of everyday present reality.... The central fact in Black Science Fiction-self-consciously so named or not-is an acknowledgement that Apocalypse already happened: that (in Public Enemy's phrase) Armageddon been in effect (Sinker 1992).

Thus Afrofuturism (for Public Enemy) begins with the End Times. Time is the accumulation of the apocalypse and its aftershocks. Lisa Yaszek also draws attention to how Afrofuturism interprets the present as already science fictional in its accumulation of past futurisms and their aftermaths: a post-Armageddon wasteland of exile and "Alien Nation" following from the abduction experience of Atlantic slavery (2006). Thus, like Monáe, Sinker suggests a more complex allegorical operation at work, in which representation exceeds its symbolic correlative to a referent and becomes a Weltanschauung-a worldview of cyclic perception and interpretation, a way of being/becoming in the world that accelerates the reality of the irreal, drawing the cycles of the future into the present in the same moment that it unearths 
the past's futurisms, the effect of which is an abandonment of consensual "reality" and its norms:

The ships landed long ago: they already laid waste whole societies, abducted and genetically altered swathes of citizenry, imposed without surcease their values. Africa and America-and so by extension Europe and Asia-are already in their various ways Alien Nation. No return to normal is possible: what "normal" is there to return to? (Sinker 1992)

Sinker's text provocatively demonstrates how Afro-futurology, inclusive of its cyclic reinterpretations of the past, alters the coordinates of the present: the contemporaneous "as-is" is revealed by Afrofuturism in its constitutive temporal abnormality. Such temporal revelations are thus transformed by Afrofuturism to un-earthings. Both Sinker and Mark Dery (1994) recognised how the Afrofuturist undertaking is disruptive to white-washed visions of the future, just as it likewise exposes the colonization of the past, what Sun Ra called the "real fictions" and "manufactured memories" that make up the all-but-erased deep history of the Afrodiaspora ( $\mathrm{Ra} 2005)$. If the Afrodiaspora rarely saw itself represented in mid twentieth century futurology-notable in the absence of Africanist representations in the 1964 New York World's Fair (Samuel 2007) — today the past of Atlantic slavery is at stake, with recent educational reforms in the Lone Star state attempting to erase its traumatic history through underhanded semiotics, as Atlantic slavery is abstracted into the "Atlantic Triangular Trade". ${ }^{15}$ In all these cases, and as Gilroy reminds us, we need to "be alert to the politics of temporalization" (2004: 339). Kodwo Eshun, in his 2003 essay on chronopolitics, outlines the dynamics of one of Afrofuturism's signature operations, its temporal politics:

By creating temporal complications and anachronistic episodes that disturb the linear time of progress, these [Afro]futurisms adjust the temporal logics that condemned black subjects to prehistory. Chronopolitically speaking, these revisionist historicities may be understood as a series of powerful competing futures that infiltrate the present at different rates (Eshun 2003: 297).

My turn to chronopolitics and cyclicity here is in part a response to Gilroy's call, at the end of Between Camps, in which he argues: "we need self-consciously to become more futureoriented. We need to look toward the future and to find political languages in which it can be discussed" (2004: 335). Gilroy hints at such a language in a passage on Afrofuturology, and in particular his focus on "music and musicians" of the "black vernacular" who have turned to "extraterrestriality, futurology, and fictions of techno-science", precisely because "denying the future and the right to be future-oriented became an integral part of the way white supremacism functioned during and after the slave system" (2004: 337). Yet "black appeals to the future", or at least Gilroy's invocation of such appeals, already has a past, a particular signature of futurism. Gilroy laments the passing futurology of antiracism, just as he laments the loss of 1970s-styled Afrofuturism and how "people no longer play with the possibility of departure from the planet in the same spirit with which their predecessors 
had entertained the idea of return to Africa" (2004: 341; 350). I would like to suggest a few points at this time: first, that "the future" is not just (in) the future, but a particular sedimentation of past signatures whose future is yet to-come. And second, that such sedimentation has cycled past Gilroy's focus on mid-20 $0^{\text {th }}$ century Afrofuturism (which, according to Gilroy, in-itself resurrected the spirit of Marcus Garvey and his "Back to Africa" campaigns). Monáe's contemporaneity, as it references the Afrofunk of the '60s to '70s, but also Weimar modernism and ' 80 s electro-funk, suggests a novel unfolding of futurist cyclicity in our own time. A pervasive futurity-to-come propels Jeff Mills and techno music, as well as electronic music's futurology in general-the latter unfortunately absent from Gilroy's repertoire of Afrofuturology.

Sun Ra suspected that "invented memory" was "placed in the minds of what is called man, in order to keep same from looking backward into a void... Because of what has happened" (2005: 60). Throughout his poetic philosophy, Ra often depicted how the Afrodiaspora has been systematically excluded from the privilege of writing (its) history-or projecting its futures. Its conspicuous absence, however, often no better mirrors its tokenistic representation. Etienne Balibar reminds us that the stereotype of the racialized "community" is a contradiction "which sees an identity as community ascribed to collectivities which are simultaneously denied the right to define themselves" (1991: 18). This right of definition, in history and toward the future, situates chronopolitics as a "political language".

Strangely, chronopolitics remains a scarcely recognised field of political intervention, even as Afrofuturist science fiction has sought to address absences of Afrodiasporic futures. In the militarist and masculinist white visions of $20^{\text {th }}$ century antiseptic science fictional futures-more or less leading up to Star Trek's debut of Lt. Nyota Uhura in 1966-there was nary a body of colour to be found. ${ }^{16}$ Robots and Russians were more plentiful. The word "robot", coined by Czech writer Karl Čapek in his 1920 story Rossum's Universal Robots (R.U.R.) —and as Paul D. Miller reminds us ${ }^{17}$-is a metaphor for "slave". Keeping this in mind, we can begin to analyse how, in "Golden Age" science fiction, the figure of the excluded and racialized other had nonetheless been insidiously included: the other had just been sanitized as metallic robota, "their" troublesome attributes of consciousness and demand for "human rights" quietly erased through deferential reprogramming. Isaac Asimov's Three Laws of Robotics that command the preservation of humans-first introduced in the short story "Runaround" in 1942-are equally at home on an antebellum plantation as on $22^{\text {nd }}$ century Mars. ${ }^{18}$

The similitude of future robotica to past slavery-or of a future dystopia to its past "hells on earth" - is not lost on Afrofuturist authors such as Octavia Butler, who in Kindred (1979) deployed the sci-fi device of time-travel to revisit southern plantation slavery. We might interpret such a literary device as precisely chronopolitical. Monáe's androidal incarnation as Cindi Mayweather likewise conducts an Afrofuturist chronopolitics; we are reminded again that in the invention of the future, it is the manufacture of the past that takes its form in the uncanny return of the repressed. The android, in this respect, marks the uncanny incarnate, as a robot made to look as if human-a point not lost on Fritz Lang. 
Afrofuturist interventions in chronology hold a purpose. By imagining alternate futures-a process that requires a simultaneous revisioning of the past, but also its unconscious return - the coordinates of the present are shifted. New and hitherto impossible realities come into effect. As well as past irrealities. Ra's Afrofuturist take on Kemet, for example, sidesteps the claims of truth and authenticity argued for by Afrocentric revisionist history, pursuing instead what he calls MythScience, or the impossible embodiment of "a living parable/parallel", an "AlterDestiny" that uses creative fictions of past and future to reorganise the present coordinates of fact so that he, himself, may walk Earth as a Living Myth. Ra meditates upon rendering the "impossible" a reality:

Wisdom on its abstract planes

Uses myth as medium to understanding

Thus a living parable to the outward

or inward truth

Is every myth:

And from the myth you can see

the likeness of the truth-out

— Sun Ra, excerpt of "Living Parallel (1972)" (69: 2005)

\section{The Messenger Returns}

So far, celebrants and critics of those [Afrofuturological] cultures have had to consider the power of meaningful sound before they could move toward the different and perhaps less demanding tasks involved in analyzing the visualization of the extraterrestrial and the futuristic in racialized forms (Gilroy 2004: 342).

Techno THunders From the SPEAKER STACKs. Symbols of outer space and alien contact abound (see fig. 2). Mills is piloting his project entitled The Messenger / Sleeper Wakes (2012), the liner notes of which read: "The Sleeper explores time and the absence of it, the method of creating music for a specific time in our future, the preparation and calculation of what could and will be and most importantly, what we do with this sensitive and rare opportunity". Mills is preoccupied with the future, with time, and unfolding music that will accelerate what he sees as its "cyclical" effects. In his Star People performance text (2013), Mill emphasizes the persistent unfolding of change, in which "there must always be destruction of the old to bring forth the new". Yet such destructions are in themselves not new: there is a "compulsive" history of erasure. Perhaps thusly, he states: "Cycles in our evolution are compulsive, never-ending and guarded by the nomadic reasoning that we live for today, but we dream for tomorrow". 


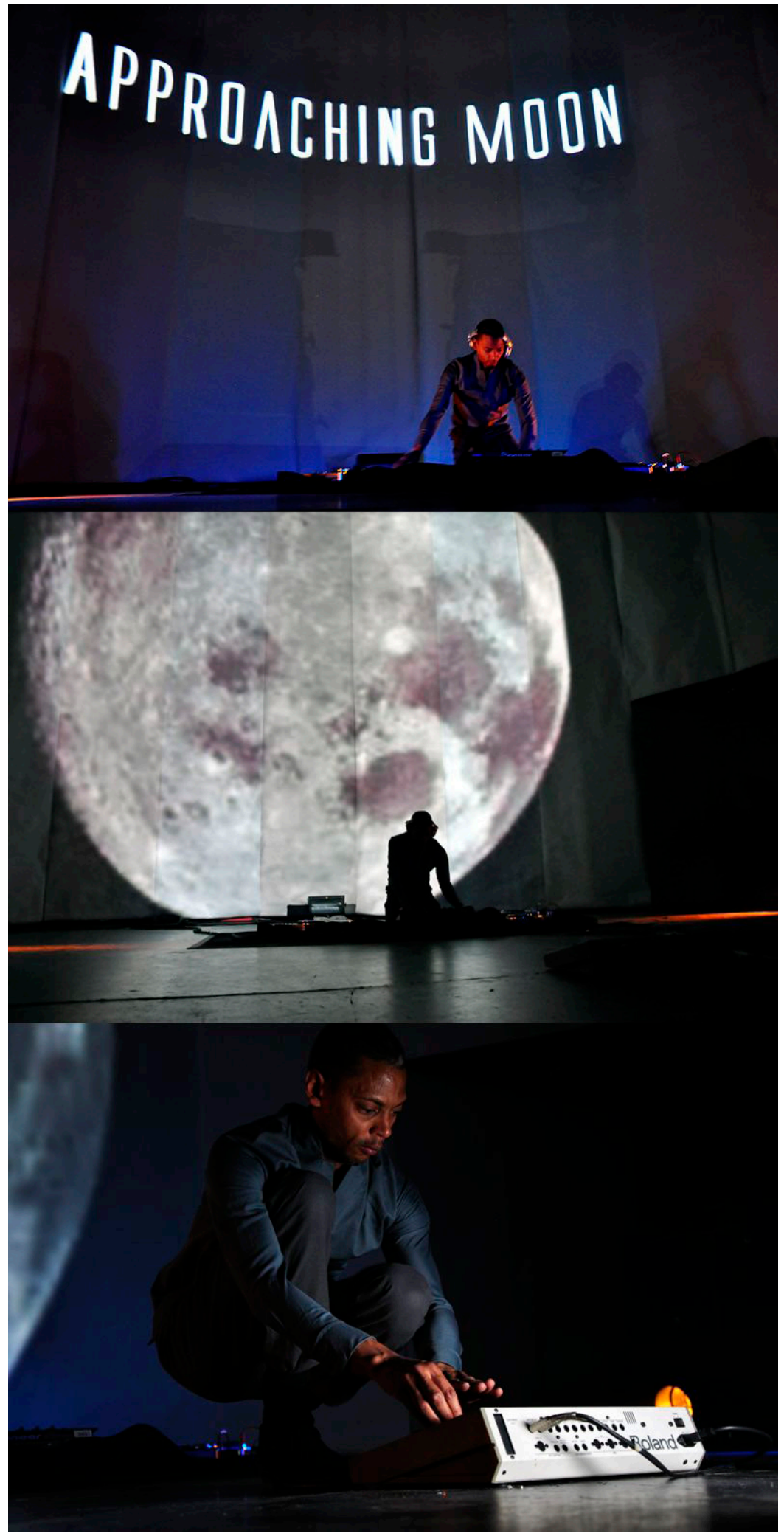

Figure 2. Jeff Mills, Sleeper Wakes, MUTEK 2012, Montréal. Photo: tobias C. Van Veen. 
Throughout his twenty-five odd years of techno production and DJing, Mills has consistently pursued the concept of cyclical change, a concept that techno music shapes into aesthetic discipline through its compositional focus on mechanical, industrial, and otherwise alien forms of sonic repetition in electronic music. Unlike lyrical music, techno presents added challenges for scholars. Its music must be approached on at least two registers: that of its affect (the embodied impact of its soundwaves on the dancefloor) and that of what Eshun calls its "sonic fictions" (1999), the textual, visual, and conceptual productions that surround, but also inflect, its recording and performance: its Weltanschauung.

Operating in the register of affect, the signature style of Mills' techno-marked by its tight, four-bar loops, accented with polyrhythmic percussion and the force of its synthesizers, whether exploring realms of pounding distortion, sci-fi soundtracks, or Africanist and Latin patterning-always sounds as if it is but an echo of a future music to-come. Yet once caught in its vortex, a body bound to the speaker stacks, Mills warps the experience of time, and all feels timeless: hours are spent on the dancefloor as if abducted to the moment of an ever-repeating, ever-unfolding cycle of what Amiri Baraka once called "the changing same".

Then there are the sonic fictions of Jeff Mills, AXIS Records and Underground Resistance. On the Sleeperwakes.com website, Mills' first entry is a report from his travels to Mercury, where he observes "that the Planet does exercise a earthlike character in terms of its liquid deposits" (2009). He goes on to write: "I'm not sure I'm the same person I was then after witnessing such a array of occurances in my travels [sic]". Apparently, Mills has become the Messenger, the last surviving member of a future Earth terraformed by invading aliens. Mills' sonic fiction appears to hint at a further step, one undertaken only by a few Afrofuturists: that of becoming, of a transformation of subjectivity, toward the alien, android, cyborg, or other-worldly. Or even just a self-perception as already within the future: the Messenger is a time traveller, here to warn Earth of future doom; a technochronoprophet. The 2012 release of The Messenger explains the doomsday scenario, its liner notes reading:

The Messenger is the fourth chapter of a musical science fiction series. This chapter explores the recycling of planet Earth and the end of all Earth's life forms. Doomsday appears to be nothing more than an agricultural reconditioning phase controlled by an alien life forms [sic], they reveal the explosive reality of creating the Human animal for the production and harvesting of Dreams. Caught between secretive human+alien relationship, The Messenger pleads the case for more time so that humans can evacuate Earth and save innocent lives-but time has run out.

Mills' written statements identify himself within his Afrofuturist mythsystem: in a reversal of white saviour myths - in particular, the allusions here to The Matrix (1999), in which humans are harvested by machines for energy, and Dark City (1998), in which humans are harvested in cyclical time for their souls-Mills is the Messenger, and like Will Smith's character Robert Neville in the zombie apocalypse film I Am Legend (2007), the last (black) man standing. Mills' personification of a character in his own mythsystem resonates with the Afrofuturist tradition of adopting alien, cyborg, or machinic identities that perform 
the double task of both allegorizing and transforming the embodied performance of blackness. Or rather, surpassing an indeterminate threshold, the performance of identity shifts into a becoming: an exodus from raciology in which the markers of blackness are no longer determinant nor referential. One becomes other to or from the other. Earth is left behind. I would like to suggest that Afrofuturist becomings provide an escape from the "constraints" of "black community", in which, as Paul Gilroy argues, black artists are confined-in expression but also analysis—to allegorizing or representing "race" (1993). Picking up on Balibar's quote above, this is to say that the markers of community stereotype those "within" it; in Gilroy's words, community provides its racialized members with "an imaginative entitlement to elaborate the consciousness of racial adversity while limiting them as artists to the exploration of that adversity" (1993: 182).

Afrofuturism suggests a technology of the self that undertakes a transformative becoming. Sun Ra, the ancient black alien deity from Saturn, is perhaps exemplary in this respect, turning to a legal change in name and erasure of his human records in the lifelong dedication to becoming alien (see Szwed 1998). Ra exceeds the allegorical role of performative identity: he becomes, in his own words, a "Living Myth", a title whose inherent contradiction accentuates the mythical operations of Afrofuturist revisionist history, in which Ra becomes the embodiment of the ancient black pharaoh, alien ruler of Kemet. Ra's becoming embodies a chronopolitical gesture that flees Earthly raciology precisely to transform it: to seek an alien alterity to racialized otherness. But if Mills has become "the Messenger" - a designation that likewise has resonance within $20^{\text {th }}$ century Africentric history, as the title of Elijah Muhammed, founder of the Nation of Islam, Messenger of Allah-who was he before?

Earthly history tells us that Mills is founding member of Detroit techno collective Underground Resistance (UR) with Mad "Mike" Banks in the late 1980s. Formerly known as the Wizard, Mills transformed the mixed-genre scratch-turntablism he pioneered on Detroit radio into an aggressive, rapidfire style of techno turntablism as one of two UR Assault DJs (the other, Rob Hood). ${ }^{19}$ Leaving UR in 1992, Mills founded the techno label Axis, developing a minimalist yet polyrhythmic production style that pushed the boundaries of distorted, 4-bar loops, haunting melodies, and industrialist palettes. It was with his sublabel Purpose Maker that Mills gained planetary recognition, incorporating Latin percussion into a repertoire that culminated in the emblematic track "The Bells" (Kat Moda EP, 1997). Over the past decade and a half-though audibly since his soundtracking of Fritz Lang's 1927 film Metropolis in 200020 - Mills has explored ever more science fictional themes in his music productions and visual imagery, returning to Afrofuturist concepts of outerspace realms and alien contact first charted under the X-102 alias with Mad Mike and Rob Hood, who on their celebrated 1992 release, X-102 Discovers The Rings of Saturn, combined minimalist acid techno with liquid basslines and "spiritual" synthesizer pads. ${ }^{21}$ On the rear of the 12-inch sleeve, above a stark image of the outer planet's rings, the text reads: "Imagine being in an atmosphere where all your God given senses are ineffective, where your existence is a mere fragment in a ring orbiting a planet. You may find yourself 
caught in the state between the rotation of motion and the rotation of life circulation". Caught: captured by sound, abducted into space, and transported to an inhuman plane of existence as inanimate matter drifting among Saturn's rings-and circling high above the birthplace of Sun Ra. Coincidence? ${ }^{22}$

\section{In Orbit to the Jungle Planet}

A SUBSTANTIAL ASPECT to appreciating the affective force of techno is registering the intangible imaginary of its concepts. Mills writes that the concept album should "materialize an idea or theory, to try to explain with music a certain place or a certain thing" (in Eshun 1999: 07 [132]). In this respect, Mills' releases and performances are inscribed with sonic fiction, "the packaging which works by sensation transference from outside to inside", inclusive of the material, print, and physical wrappers of a record release, from its gatefold images to its liner notes (Eshun 1999: 07[121]). Two new sublabels of Mills' Axis Records, Something From The Sky and Taken, feature label imagery from 1950s science fiction films. Stark, black-and-white photographs depict white actors gazing skywards. Frozen in frame, hands often shielding their eyes, these archaic symbols of 1950s-era science fiction gaze out past the black rings of the record, as if symbolically trapped on their small, rotational planet, surrounded by the dark rings of the record's wax. Who or what is this "something in the sky"? Who has been "taken"? Who or what has been left behind?

This is not the first time that Mills has drawn attention to the black materiality of the 12-inch record. The record is perhaps the ultimate commodity form in recording music. Increasingly a fetish object surpassed by digital forms that promise better fidelity, durability, and portability, its materiality nonetheless ensures its persistence, insofar as its surface offers both the fictitious imprint of sonic authenticity-signaling its sacred role in DJ culture-as well as a precise control surface for turntablists. In its materialization of the commodity form, the record serves as a "practical allegory" to that of slavery: its default blackness resonates with the reality of enslaved commodification. Thus tinkering with the material concept of the record, and its symbolism, takes on higher stakes than at first envisioned.

Records are also, crucially, circular: they rotate. They have rings. They allegorize the very concept of Ra's birthplace, Saturn, and serve as a homage to the concept of Afrofuturism itself. Speaking of X-102 Discovers The Rings of Saturn, Mills says that "The label itself is the actual planet, the grooves are the actual rings, so in a certain way you can give the impression that the grooves are the rings of Saturn" (in Eshun 1999: 07[133]). The concept is rendered material in sonic and visual registers: sonic fiction becomes tactile. As Eshun remarks, "The mastering, sequencing and timing of the album, the track, the label, the sleeve, the title: the conceptual potential of each is materialized" (1999: 07[133]). Of course techno music strives to materialize the affective resonances of its science fictional concepts through soundwaves, transmitted at high volume on the dancefloor: the synthetic bleeps and otherworldly rhythms are engineered to transport the dancing body to other worlds through sonic affect alone. The Afrofuturist art of techno, however, demands more 
of its listener than just ecstatic dance. Afrofuturism propagates its Weltanschauung through materialized MythSystems, of which Sonic Fiction is a part (Eshun 1999: 07[103]). Through artwork, conceptual performances, and texts, Afrofuturist techno distinguishes its sonic universe from similar but conceptually bereft patterns of club fodder-the latter which Mad Mike calls the "Attack of the Clones". 23

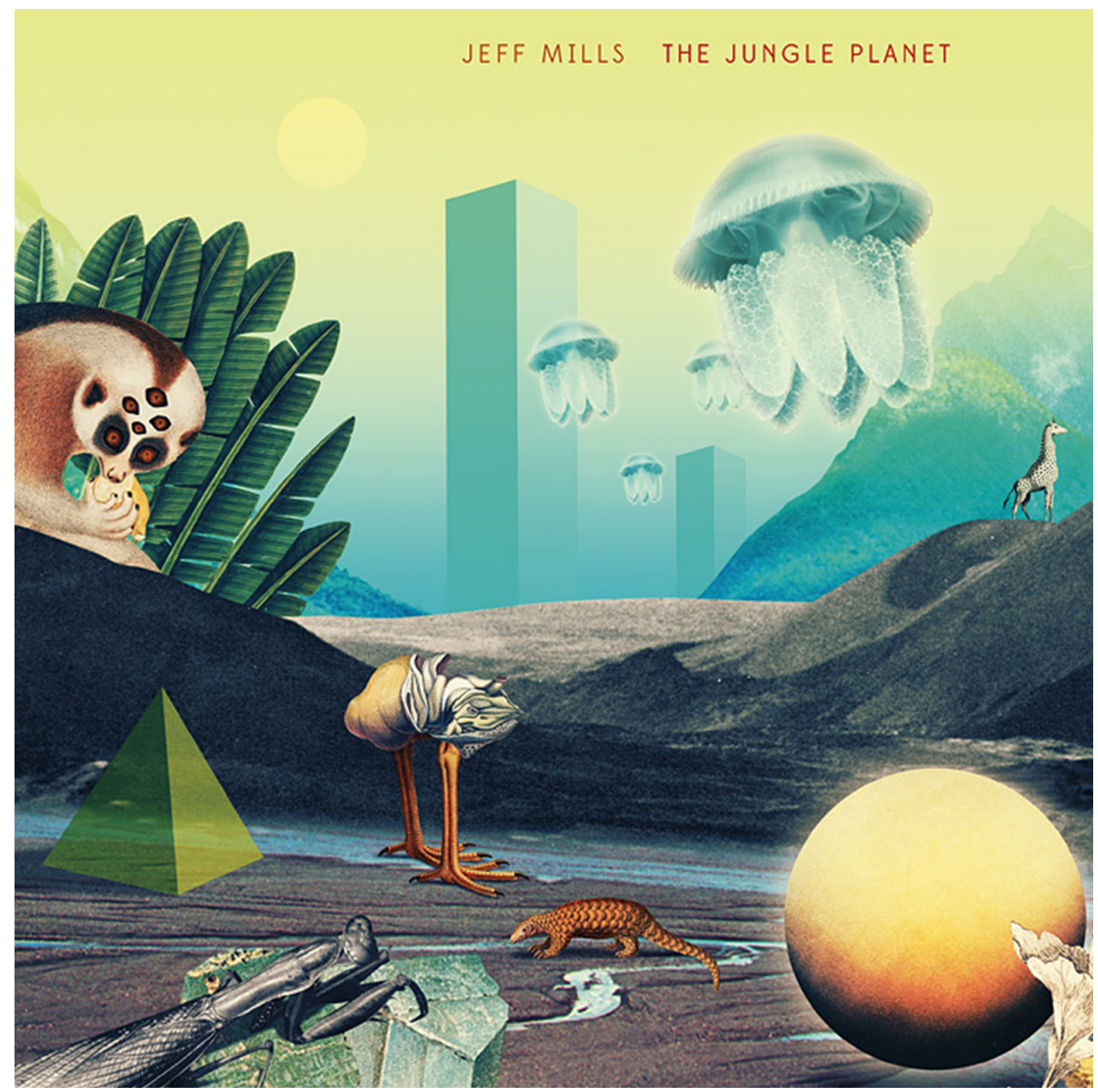

Figure 3. Jeff Mills, The Jungle Planet (2013). Artwork: Julien Pacaud. 
Mills' 2013 album, The Jungle Planet, is the fifth in his Messenger series (see fig. 3). With each release, Mills has unfolded an extraterrestrial narrative of the eschaton, as the Messenger bears witness to the end of humankind through disastrous first contact with a terraforming alien species. From the AxisRecords.com website, Mills details the discovery of The Jungle Planet:

After aliens agriculturally recondition Earth and purposely cause the end of the human species, with no home or place he can return to, Earth's only survivor known as The Messenger embarks on a search to find the residue of human dreams in an attempt to re-create his species once again. He desperately travels to a place where the concepts of human animal were designed. A place in another dimension in space to a planet that is beyond belief. A super planet, 300 times the size of Jupiter with three Suns, two solar and one of an unknown source. With four hour days and a near constant cover of darkness, growth is constant. The planet supports trillions upon trillions of life forms. It was here that the concept of human and life and dreams for commercial reasons was created. In a last ditched effort to restore his race, The Messenger travels to and searches the planet, through its bizarre and obscure landscape with fragile hopes. This planet is called the Jungle Planet.

What is Afrofuturist techno? "Techno is a music based in experimentation; it is music for the future of the human race", states the Creed of Underground Resistance (UR). Techno is a means of interstellar communication: "alien transmissions from the Red Planet", as UR's Martian label declaims. Techno is sonic shock tactics in the language of UR and Mills: "waveform transmissions" and "sonic landmines" designed to smash the "wall between races" erected by the programmers of the "mediocre audio and visual programming that is being fed to the inhabitants of Earth" (Creed).

According to Eshun, the effects of such sonic fictions are powerful: "Concept feeds back into sensation, acting as a subjectivity engine, a machine of subjectivity that peoples the world with audio hallucinations" (07[121]). The combination of sound+concept, argues Eshun, has the ability to transform subjectivity. The timespace of such an encounter is the dance floor, where subjects are immersed in auditory stimuli, hallucinating freely. During the dance floor trips, one travels: Afrofuturist techno-like Ra's "outerspace jazz" - abducts the listener to other worlds. It seduces the dancing body into alien and machinic becomings through sonic fictions that depict its music as transmissions from alien planets or android producers.

\section{Techno: Astrologies of the Streets}

AdmitTEDly more abSTRACT than lyric-bound music and its verse-chorus structure, techno abstracts itself from Earth at greater acceleration. Consequently it often deflects or refuses an allegorical role to Earthly concerns. But such "abstraction", I would argue, heightens the concrete encounter with sonic affect: with no lyricism to interpret, the experience of techno is one of interpreting-through dance-its rhythmic affect to its sonic fictions. As Eshun writes, "Techno disappears from the street, the ghetto and the 
hood" (1999: 07[102]). The alien and offworld nexus of techno music doesn't "represent" Earthly concerns, geographies, or identities in the way that gangsta' hip-hop or West coast $\mathrm{g}$-funk articulates-in a double-movement of critique and fetishization, celebration and mourning - the violence of impoverishment, the confines of ghettoization, or the anger and frustration of structural unemployment and systemic discrimination. ${ }^{24}$ This is not to say that Afrofuturist music - including its hip-hop — turns a blind eye to earthly conditions. Hip-hop in general deploys what Tricia Rose describes as its "primary properties of flow, layering, and rupture [that] simultaneously reflect and contest the social roles open to urban inner-city youths at the end of the twentieth century" (1994: 22). The difference is that Afrofuturist techno defers the contestation of urban paradigms through their (troubled) representation: rather, it seeks exile, inhabiting alternate realities, projecting AlterDestinies, and "representing" an impossible yet enticing unearthly becoming for the abducted: like Ra's jazz, it "travels the spaceways". Emcee Killah Priest of Wu-Tang Clan describes the Afrofuturist relationship to the terrestrial ghetto as one of conducting "astrologies of the streets" ("The Pwowr (Problem Solver)", 2013). With the lyrics of Priest in mind and, in respect to Mills, the otherworldly rhythms of The Jungle Planet, we can imagine how the terrestrial is transformed into an uncanny topography. Mills and Priest elevate the listener to a position where Earth becomes other, as if viewed from orbit, its strange behaviours witnessed with an extra-terrestrial perspective. Though such otherworldly perspectives, Afrofuturist music conducts an AbWeltanschauung or offworlding of erstwhile humanist approaches. We may imagine how Afrofuturist music off-worlds the listener by phaseshifting the mind and body with futurist rhythms and science fictional sounds; rather than becoming grounded in "ghetto life" we are unearthed from terrestrial points of reference and the grounds of representation. With Afrofuturist sound, we are initiated into the imaginary of an other-space-and space of-the-other-to-enforced-otherness-that seeks (and thus unearths) elsewhere as well as elsewhen.

\section{Star People}

IF SOUND is capable of producing hallucinatory effects-including the warped "chronopolitical language" explored above-there remains limitations to the visual allegories of sonic fictions. Gilroy broaches such shortfalls when he writes that "seeing and hearing the future need not add up to the same thing" (2004: 342). I would like to draw this missive to a close with a critique of the limitations of Afrofuturism, not in the register of the visual per se, but in respect to the limits of representation.

In the context of aesthetic appreciation, an insufficient attempt at visual representation can diminish the impact of sound alone. But visuality can also register the limits of representation by attempting to literalize what is otherwise transformed by way of sound. The same goes for the representative aspects of text. Such limits were highlighted in a performance by Jeff Mills at the New Forms Festival (2013) in Vancouver, Canada, where Mills debuted his new audiovisual performance, Star People. Thoughout the three-hour performance, the visuals intermittently superimposed the faces of First Peoples-wearing headdresses and otherwise adorned in "traditional" wear-upon cosmic starscapes (see fig. 4). ${ }^{25}$ 


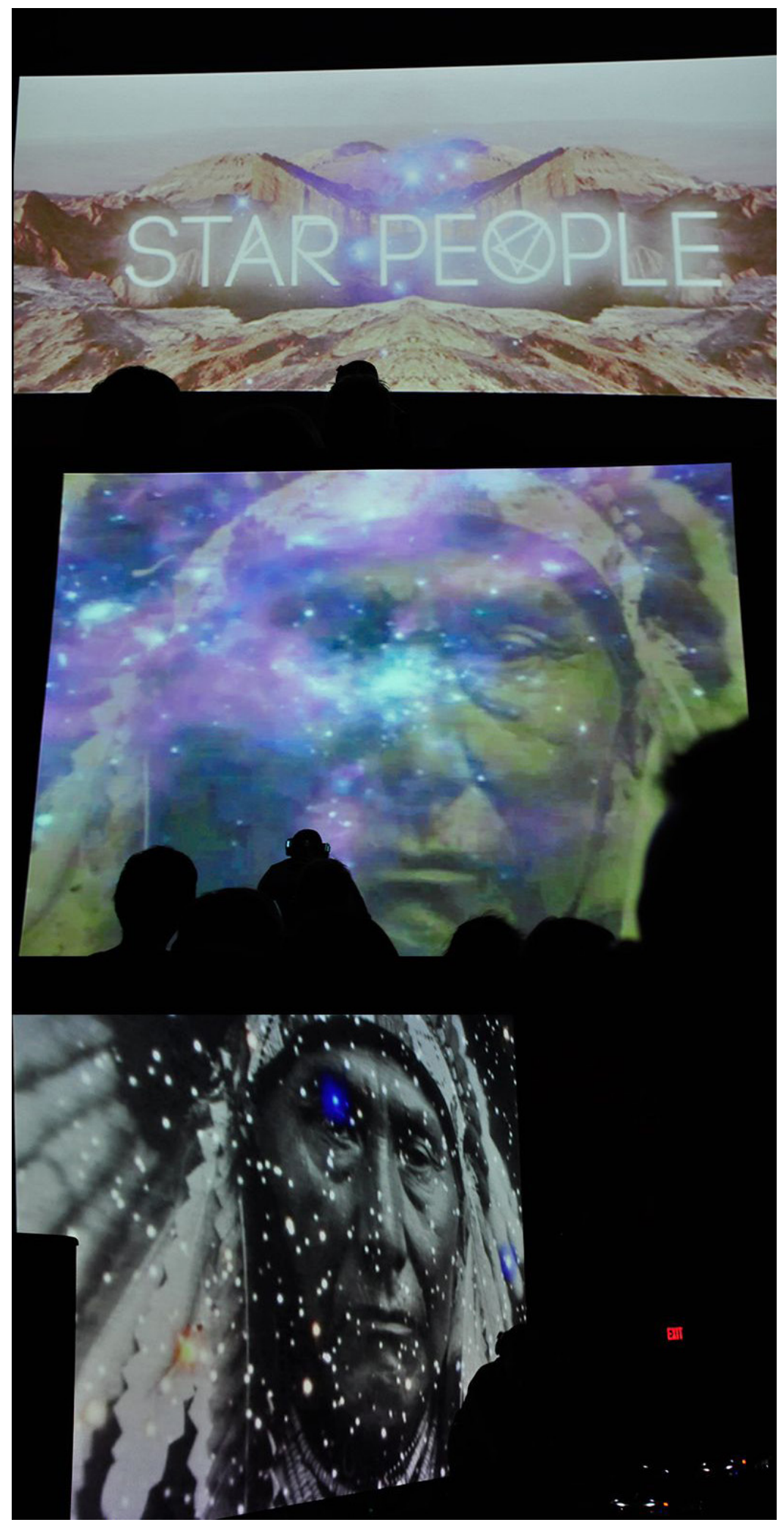

Figure 4. Jeff Mills, Star People, Vancouver, Canada (2013). Photo: tobias C. van Veen. 
In the Star People text, Mills discusses his concept of cyclicity, before writing:

In Indian culture, the consistent belief in the co-habitation of humans and aliens is a relationship that has existed long before their land of America was visited by the Europeans.

The common belief is this: Star people descended from the sky and landed in the mountains around Indian tribes. They became friends and teachers. Children were born from this relationship. At the age of three, these special children were taken up into the Stars to learn. In the later teen years, the children are brought back to Earth by the visitors and reunited with their Indian family. These special people walk the Earth and are among us now.

Jeff Mills presents STAR PEOPLE. A 3 hour musical observation and journey on the relationship between humans and our paternal connection with visitors from the Stars.

Mills' text is evidently problematic, not the least its mode of address. ${ }^{26}$ Though Mills' reference to the Star People parallels various Afrofuturist and populist myths of ancient alien contact, the text generalises the beliefs of multiple peoples, and risks objectifying the "Star People" into an Afrofuturist MythSystem much in the same way that colonialism appropriated the symbols, performances and cultural signs of First Peoples while, at the same time, tokenizing their presence. ${ }^{27}$ Projected upon the screen, the "Star Peoples" appeared anachronistic - as if "they" live in the past, always in "traditional" costume, even as the text emphasizes their contemporaneous existence. What chronopolitical futurisms otherwise to the "traditionalist" stereotype could have been imagined? The problematic here is compounded by a language of ownership through the other that raises questions of who speaks for the Star People, just as their representations depict a mute faciality. Besides its sympathetic resonance with Star Peoples, how does Mills' performance differ structurally from appropriations of "Indian tribes" and other such "Cowboys \& Indians" stereotypes that provided the "exotic" content of Golden Era sci-fi?

The critique I proffer here was reflected elsewhere. James Bates, Arts Beat reporter of campus and community radio station CiTR 101.9FM, writes that

I was excited to see how the connections between certain aboriginal cultures and alien mythology would play out. This was perhaps the biggest disappointment. Maybe I should have been tipped off by the heavy use of the word "Indian" denoting North American indigenous people in NFF 13's own description. But simply superimposing images of first peoples onto the aforementioned space images does not serve as any substantial comment or exploration of the Afro-futurist ideas Star People seemed to draw inspiration from (Bates 2013). 


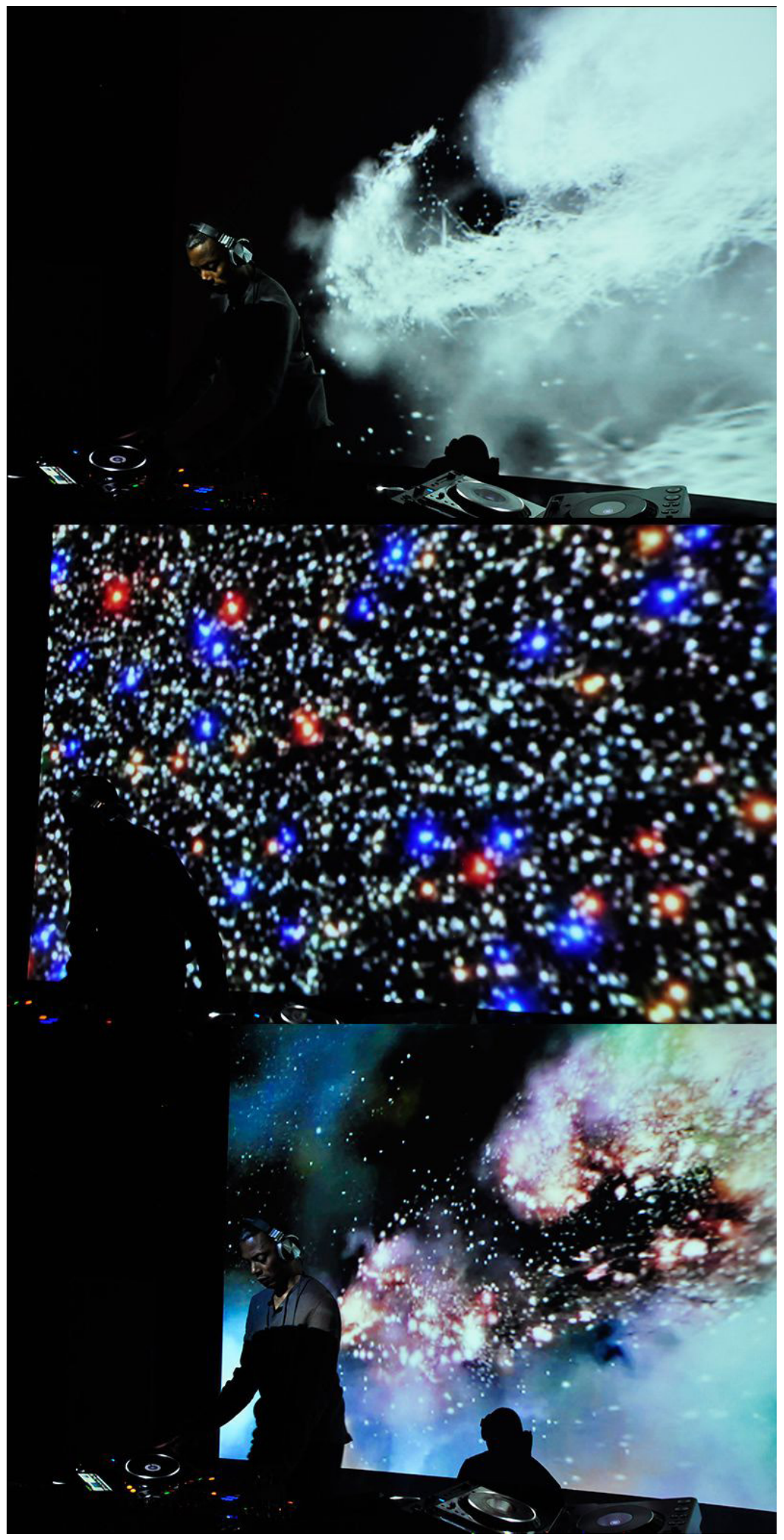

Figure 5. Jeff Mills, Star People, Vancouver, Canada (2013). Photo: tobias C. van Veen. 
Bates goes on to write, "If I had arrived Thursday night prepared to dance, without any expectation of narrative or mythology, I probably would have enjoyed the night a lot more", suggesting that, on the aesthetic level, he had expected a more cohesive integration of the visual to the sonic registers, precisely because of the role Mills' sonic fiction played in contextualizing the performance. ${ }^{28}$

However, I do not wish to imply that Mills' choice of representations were distasteful. On the contrary, the photographs were aesthetically stunning portraits. Nor do I think that the concept of creatively exploring First Peoples' beliefs in alien contact is in-itself at issue; utilising the myth without addressing its living embodiments would only erase First Peoples from the picture. To paraphrase Rey Chow, I too believe that the "mixing of genes and genres" deconstructs raciology (2002: 17). The problem, however, is that the visual representation of Star Peoples, as a literalized allegory of the concept, was not Afrofuturist enough: the imagery tried to ground the concept in the authenticity of a racialized/facialized other whose mute visage performed the stereotypes of "Indian" stoicism and silence. The transformative capacity of allegory to exceed Earthly reference was abandoned; instead allegory literalized raciology as if to authenticate-through a stereotyped faciality of the other-Mills' attempt to craft a MythScience from Star Peoples. More intriguing would be to imagine alternative becomings for Star Peoples-as well as depictions that underscore how, in "walking the Earth" today, the alien among "us" hide in plain sight.

If I close with this scene, it is not because I harbour a desire to single out Mills' work for critique; it was chance that I attended Star People while crafting this text. ${ }^{29}$ Mills' five-CDJ set was an advanced exploration of offworld techno that left the dancefloor-an eclectic mish-mash of generations, nationalities, genders, and ethnicities-teleported to imaginary realms (see fig. 5). However the performance serves as a means to demonstrate the limits of Afrofuturism by way of its shadow: that Afrofuturism articulates the means to dismantle raciology through operations of becoming and chronopolitics that unearth-or at least render uncanny and ambiguous-representative allegory. And that its escape velocity can fall short if its forces remain grounded in literalizing representation and authenticity.

\section{InTERPLANetARy CoSmospolitanism: The FUtures of Afrofuturism}

Spanning two Generations of Afrofuturism, ${ }^{30}$ Jeff Mills and Janelle Monáe signify a planetary counter-tradition whose contours remain to be traced in their emergent complexity. As the likes of Mills and Monáe expand the repertoire of Afrofuturist sounds, signs and strategies, new questions and concepts arise that renew ancient meditations. What does it mean to be designated (un)human? What are the techniques of becoming otherwise? What do such becomings mean for subjectivity, for "race" and "blackness"?

Though Afrofuturism is in part an inventive countermand to-and thus implicated within - raciology, it differs from strategies that would reify (and celebrate) the latter in ("bio")cultural forms. ${ }^{31}$ The alien and the android model quasi-autonomous becomings that are constitutively open-ended. These figures also arise from a remix of world cultures. Mills 
and Monáe have both articulated Afrofuturism's android, alien and machinic becomings to the $20^{\text {th }}$ century European avant-garde as well as science fiction. ${ }^{32}$ Monáe's black-andwhite sets and costumes allegorize the epidermal polarization of raciology to the film stock and noir shadowing of Fritz Lang's German Expressionism. Monáe, a third-generation Afrofuturist, is particularly attentive to the ways in which the android speaks to (post) modernist forms of bondage - and autonomy.

Monáe has also set a new standard in reworking the Afrofuturist inheritance. During her performances of "Tightrope", she accepts a cape brought to her on-stage, as if shouldering the mantle of James Brown across generations and genders (see fig. 6).

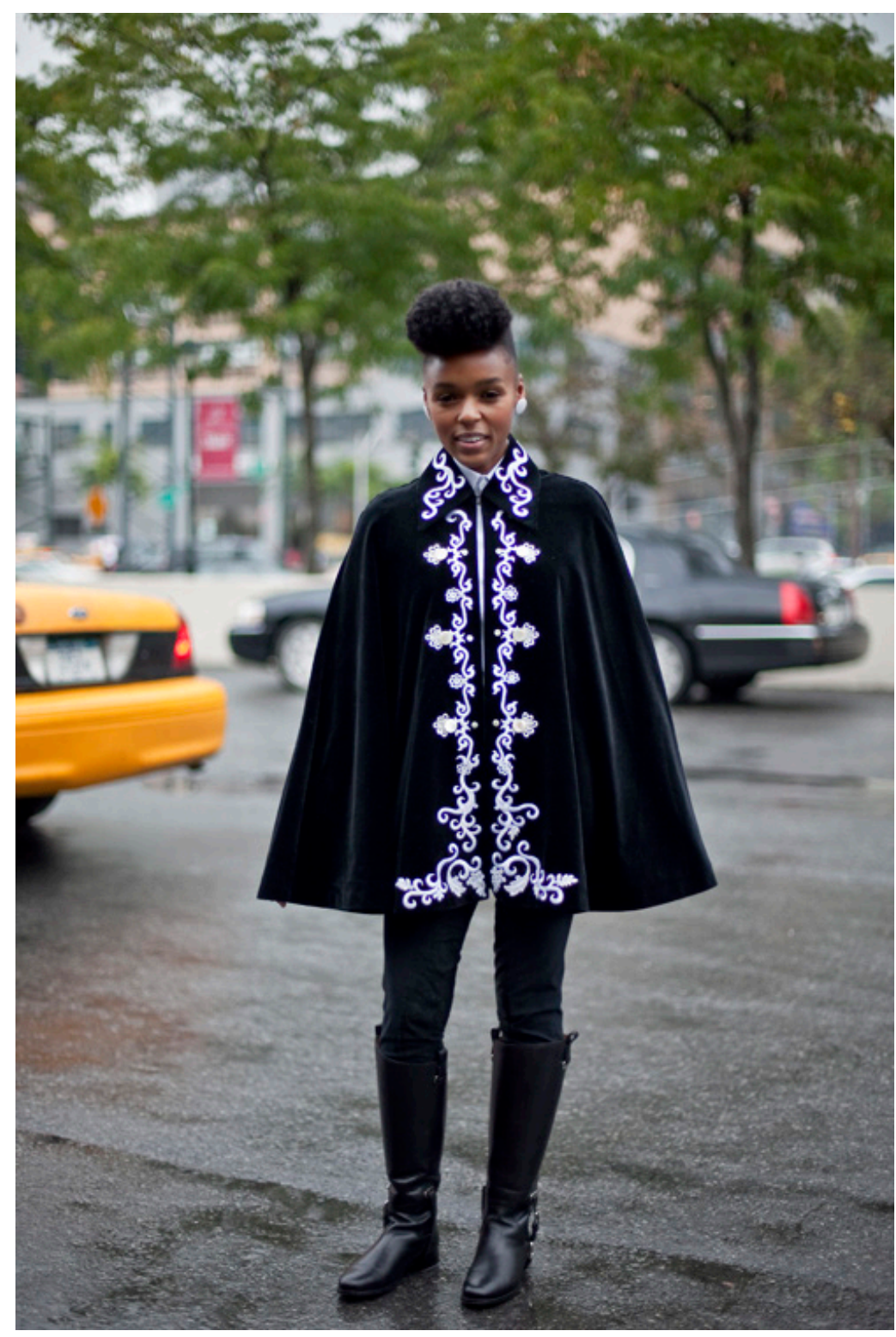

Figure 6. Janelle Monáe shoulders the cape. Photo: JanelleMonae.com. 
She ends by calling for the break "one more time" - at least five times. Her performances are theatrical set-pieces: her band swings with the precision and orchestrated movement of not only Brown's funk outfits but the big band era of Cab Calloway and Duke Ellington, while her band's dress, hair and fashion style signify 1960s soul, notably Diana Ross and The Supremes. And like funk, big band, swing - all the "rhythmachines"—both Mills and Monáe ${ }^{33}$ call upon us to dance, reaffirming the transformational freedom of the ritualistic, embodied movement that makes us all into spastic androids, moonwalkers and aliens. ${ }^{34}$ But how pervasive is the Afrofuturist inheritance in global pop and dance culture? Drawing from the master of anti-gravity ballet and robotic movement himself, the King of Pop, Monáe does the moonwalk. ${ }^{35}$ Like Michael Jackson, she dances-and at times sings-like a dysfunctional robot. ${ }^{36}$ Do not these machinic and alter-gravitational movements, encapsulated in the strange embodiment of Michael Jackson, suggest unexplored Afrofuturist pathways of what it means to become alien? ${ }^{37}$

Jeff Mills, unlike Monáe, works without lyricism and rarely with image. Performativity is inherently robotic: on stage, Mills is a composed technician, devoid of expression. His hands move with the grace of a conductor; small, precise gestures send attentive crowds into rapture. The legacy of Detroit techno is twofold: like Sun Ra's outerspace jazz, it undertakes a sonic exploration of musical boundaries. But also like Ra's monumental performances, it is tied to the ancient ritual of the experiential event, in which one is immersed in cyclic sound and transported through repetition, movement and affect to imaginative offworlds. Techno alienates: it communicates the coordinates of alien and machinic music; it de-humanizes the dancing self. While Monáe embodies the alien as Cindi Mayweather, Detroit techno abducts the audience, making its alien arrival a tangible and transformative undertaking.

As Womack (2013) has surveyed, artists are now organising around the concept of Afrofuturism, transforming its meaning and operations by reinterpreting its past. This past is constitutively intertwined with modernity and the latter's futurological narratives of progress - a teleology that was supposed to leave unhumans behind.

Can Afrofuturism proffer a means to transform such raciological discourses? In Between Camps, Paul Gilroy argues that modernity, qua the Enlightenment, is inextricably bound-up with raciology. He writes that "the consolidation of modern raciology required enlightenment and myth to be intertwined" (2004: 59). In short, MythScience is at the heart of modernity. I concur with his analysis of how the Enlightenment defines the birth of Man only by excluding the racialized slave-and the female body. Like Gilroy, I do not believe that these are grounds to reject its "universalist promises" (62), but rather to transform them, precisely because of the latter's foundational MythScience. For Gilroy, the way forward is through "planetary humanism", a discourse that seeks to abolish race in the establishment of a renewed cosmopolitanism. But is "humanism" enough? Is the "human" species the only member of the planet's cosmopolitan club? Is not "the human" just another manifest of raciology, a "race" that, while celebrating its planetary solidarity, implicitly (if not explicitly) assumes a superior relationship to the rest of Earth and its species? Afrofuturism speculates upon a third alternative for our third stone from the sun: 
a cosmospolitanism that seeks to transform species-being in a universal becoming alien. A "universality" that is no longer bound to the terrestial; a universality that affirms its alien ex-centricity to Earth through a cosmospolitanism of species. Cosmospolitanism suggests that the "human" itself is a contingent becoming, one that is well due for short-circuiting in light of the many species to which we remain hostile aliens. ${ }^{38}$

\section{ACKNOWLEDGEMENTS}

Thanks to Jonathan Sterne for everything. Thanks to Dave Pires for the deep night conversations, Sha Labare for reminding me we are not the sole alien species, Kentyah Fraser for the supreme. Thanks be to Mad Mike Banks and Cornelius Harris of Underground Resistance, Jeff Mills, Yoko Uozumi at AXIS Records, Alain Mongeau and the press team at MUTEK, Malcolm Levy and Jessica Santa at New Forms Festival, and android \#57821, Cindi Mayweather, and her cohort Major Lee. "Deprogram the programmers..."

\section{NOTES}

1 Emails to author, 9-27 July 2009.

2 Prince, the symbol of soul and titan of tight funk, perhaps needs no introduction. Outkast, the Atlanta-based hip-hop crew of André 3000 and Big Boi, perhaps do, if anything for their 1996 album ATLiens - a smooth roll through heatwaves of freaky flow-where extraterrestriality allegorizes the excluded middle of southern hip-hop to East/West rivalry, as well as emphasizing the alien-nation of southern blackness.

3 Becoming is deployed here to articulate a transformative subjective process (sujet-en-procès) that exceeds the constraints of identity and representation through repetition, hauntology and ontogenesis. To this end it draws upon the Eurocentric philosophical heritage of Gilles Deleuze and Félix Guattari, the mutable différance of Jacques Derrida, the "eternal return" of Nietzsche, and the work of Gilbert Simondon and Bernard Stiegler in articulating historical becomings of technics that modulate the "infinite finite" of différance. However, it is not the place of this article to replay such philosophical perspectives. Here, I turn to Afrofuturist modes of performative and speculative thought through music and becoming.

4 For a decent fan video of the performance, see "Jeff Mills presents..." (2012), and for a Roland TR-909 improvised set, see "Jeff Mills vs TR-909..." (2012).

5 As Yaszek writes, "contemporary Afrofuturists assume that in the future race will continue to matter to individuals and entire civilizations alike" (2006: 43). Yet, as Gilroy has argued (2004), "race" itself is subject to futurist transformation. Scholars have yet to trace Afrofuturist philosophical epistemes or the musical antecedents that would presage Sun Ra and John Coltrane's outerspace jazz. Given the mixture of religious, ritual and occult practices that infuse Afrofuturism, the future might unearth a past speculative tradition more ancient than previously envisioned. At the very least, Africanist aesthetic practices were appropriated by European artists for the future art of modernism (see Gikandi 2006).

6 I have here replaced "African-American", as I have elsewhere in other quotes, with 
Afrodiasporic". I maintain that Afrofuturism is not only an Afrodiasporic futurology (as does Gilroy, 2004) but an (inter)planetary episteme.

7 For an introductory list of Afrofuturist scholars informing (and where possible cited within) this article, see Dery (1994); Eshun (1999); Nelson (2002); Rollefson (2008); Sinker (1993); van Veen (2003, 2003a); Weheliye (2005); Williams (2001); Womack (2013); Yaszek (2005, 2006); and Zuberi (2004).

8 Or, Afrofuturist becoming disrupts Hegel's master/slave dialectic by disabusing the subalternity of the slave and transforming its unhuman status into the renegade and uncanny autonomy of becoming-alien. The alien is the excluded (temporal) term of the dialectic that sends its relentless wheel careening. This thesis, which underlies the philosophical infrastructure of this article's meditations on becoming, will have to be explicated elsewhere.

9 For an inventive and crucial reading of Dr. Octagon's "robot voodoo power" in relation to Sun Ra's MythScience and Gilroy's “anti-anti-essentialism”, see Rollefson (2008).

10 As expressed in Elijah Muhammad's Message to the Blackman in America (1965), including the origin myth of Yacub, the mad black scientist who invented the white man, and Ezekiel's Wheel, the orbiting "Mother Plane" UFO with bombers poised. The latter offers an intriguing science fictional interpretation of Ezekiel 1:16: "The appearance of the wheels and their work was like unto the colour of a beryl: and they four had one likeness: and their appearance and their work was as it were a wheel in the middle of a wheel".

11 At the time, Dery's definition focused on African-American science fiction literature, even though his examples of comics, music and film - and orbiting Rastas noted in William Gibson's Neuromancer (1984)-implicated the Afrodiaspora.

12 Like Dery above, Nelson's original quote reads “African-American”, even as Nelson, on the same page, writes of "new directions in the study of African diaspora culture" (2002: 9).

13 Which, granted Monáe's comments about being an African-American woman in the music industry, demands a thinking-through of the doubled operation of difference at work in the female android, a motif that follows from Monáe's crucial inversion of Fritz Lang's character of Maria in Metropolis (1927): from white to black, and from androidal double of the human Maria-who tricks the proletariat into infighting - to androidal rebel, hero of the droidal proletariat, who serves as mediatator between the droids and humans (the head, heart and hands).

14 And in particular, minimalist techno and dub-infected forms where the "space" around rhythms is often described (and heard) in terms of a "hauntology", which signals an unstable ontological field in which the return of the repressed ghost whispers in the track (see Fisher 2013, this issue). As Zuberi writes, "What seems to unite these diverse pieces of [hauntological] music is their attempt to capture the grain of earlier playback technologies and recording methods" (2007: 284).

15 Though the triangular nomenclature has been rescinded, similar changes remain (see Yobie 2010).

16 For a critical reading of race in Star Trek, see Bernardi (1998). Retroactive critiques of tokenism aside, the impact of Uhura cannot be underestimated; astronaut Mae Carol Jemison credits Nichelle Nichols' character for inspiration.

17 In the interview in this issue: "Afrofuturism Unbound: tobias c. van Veen in conversation with Paul D. Miller".

18 Which isn't to say that Čapek and Asimov weren't cognisant of the metaphorical status of 
robots to subaltern subjects-indeed, that was the point, as also in Lang's Metropolis. Hence the resonance of Asimov's rules:

1. A robot may not injure a human being or, through inaction, allow a human being to come to harm.

2. A robot must obey the orders given to it by human beings, except where such orders would conflict with the First Law.

3. A robot must protect its own existence as long as such protection does not conflict with the First or Second Law.

19 For a more thorough history, see Pope (2011) and Gholz (2011).

20 Which I was fortunate enough to experience at the $10^{\text {th }}$ Anniversary of Sónar festival in Barcelona (2002), where I came across a film installation of Mills' Metropolis soundtrack. Mills' Metropolis is tightly synchronised: as the workers labour repetitiously in the construction of the Ziggurat, so do Mills' industrialist loops. Both Mills and Monáe are drawn to Lang's Metropolis, for reasons that will have to be considered in greater depth elsewhere.

21 Mad Mike likens the feeling of synthesizer playing to that of playing in church (email to author, 28 May 2008). In 2008 Tresor reissued this classic as X-102 Rediscovers the Rings of Saturn.

$22 \mathrm{Ra}$ is also signified by Monáe, who as Cindi Mayweather, is stalked by black-robed figures with mirrored visages that appear to have followed her from Ra's film Space Is The Place-see the videos (and stage performances) that accompany The ArchAndroid (2010), "Dance or Die" Live (2011) and the music video for "Tightrope" (2010).

23 Conversation with author, May 2008.

24 Tricia Rose details in Black Noise how "Hip hop replicates and reimagines the experiences of urban life" (1994: 22).

25 I use the Canadian designation for indigenous or aboriginal peoples; in the United States the preferred term is Native American, though I believe it remains problematically colonial and nationalist.

26 Critically: "Indian culture" as a nonspecific naming of a multiplicity of First Peoples; the collapse of cultural multiplicity into a "common" or "consistent belief;" that "their land" was named "America" pre-contact; the transition from "their" and "they" to the possessives "us" and "our; and the assumption of a "paternal" (and not material or otherwise) connection.

27 As well as attempting to systemically erase First People through territorial conquest, colonial war and ghettoization ("reserves").

28 This criticism was also shared by Exclaim! arts critic Alan Ranta (2013).

29 Unfortunately, Mills was unavailable for interview. As a turntablist with nearly every Axis release in my crate, I hold a deep respect for his work (enough to critique it).

30 Mills, born in 1963, is now fifty; Monáe, born in 1985, is twenty-seven.

$31 \mathrm{My}$ main point here is to differentiate the trajectory of Afrofuturism from Afrocentrism, even though their history, concepts and persons are constitutively entwined.

32 Which is not to assume that the European avant-garde is solely "white", but rather that Afromodernism has been neglected (see Nuttall 2006). As noted above (see Gikandi 2006), the "avant-garde" appropriated (and reworked) abstractionist techniques from the Africanist arts that have in turn influenced Afrodiasporic futurist practices. It is just this constitutive 
hybridity that Afrofuturism seeks to accentuate-though by ungrounding Eurocentrism. Of note, Mills also turns to pioneering sci-fi writer H.G. Wells, sampling his 1910 dystopian novel title, Sleeper Wakes (2009).

33 And Nietzsche. And Emma Goldman - "If I can't dance, I don't want to be part of your revolution".

34 Monáe emphasizes dance throughout her albums, particularly "Tightrope" (The ArchAndroid) and "Dance Apocalytic" (The Electric Lady). For a detailed analysis of Mills' desire for a participatory, dancing audience, see Gholz (2011).

35 And is second-to-none in doing so to the King himself (RIP). See her short film "Many Moons" (2008), where she moonwalks backwards and forwards.

36 Like a robot gone berserk, perhaps. See Monáe's performance with Nas (2008). At the end of "Many Moons" (2008), Cindi Mayweather dances herself into the sky, defying the bondage of gravity, before she is hit by a sky-born power surge and short-circuits.

37 Might we not speculate upon the epidermal transformation of Michael Jackson as an Afrofuturist attempt to manufacture alien posthumanism? How might whiteness signify not just Caucasian identification, but the android's "chrome”? In Monáe's "Many Moons" (2008), Cindi Mayweather is initially white: blackness is applied by pressing a button by her ear. On The Electric Lady (2013), DJ Crash-Crash discusses androids "polishing chrome". For a series of (troubled?) ruminations on Jackson, see Fisher (2009).

38 I am indebted to Sha Labare's dissertation, "Farfetchings: On and In the SF Mode" (2010) for connecting Afrofuturism to a broader critique of speciest thinking, and to the voicings of the Space Ape, for the resonant phrase "hostile aliens" on the track "Space Ape" (Burial, 2006).

\section{REFERENCES}

Bates, James. 2013. “New Forms'13 Arts Review_Jeff Mills leaves Star People premise unfulfilled”. CiTR.ca. 13 September: <http://www.citr.ca/index.php/2013/09/new-forms-13arts-review-jeff-mills-leaves-star-people-premise-unfulfilled/> (accessed 13 September 2013).

Baucom, Ian. 2005. Specters of the Atlantic: Finance Capital, Slavery, and the Philosophy of History. Durham: Duke University Press.

Bernal, Martin. 2002. Black Athena: The Afroasiatic Roots of Classical Civilization, Volume I: The Fabrication of Ancient Greece, 1785-1985. Toronto: Scholarly Book Services, Inc.

Bernardi, Daniel Leonard. 1998. Star Trek and History: Race-ing Toward a White Future. New Brunswick: Rutgers University Press.

Butler, Octavia. 1979. Kindred. New York: Doubleday.

Chow, Rey. 2002. The Protestant Ethnic and the Spirit of Capitalism. New York: Columbia University Press.

Dery, Mark. 1994. "Black to the Future: Interviews with Samuel R. Delany, Greg Tate, and Tricia Rose". In Flame Wars: The Discourse of Cyberculture, ed. Mark Dery, 179-222. Durham: Duke University Press.

Eshun, Kodwo. 1999. More Brilliant Than the Sun: Adventures in Sonic Fiction. London Quartet. 
- _- 2003. "Further Considerations of Afrofuturism". CR: The New Centennial Review 3(2): 287-302.

Fisher, Mark, ed. 2009. The Resistible Demise of Michael Jackson. New York: Zero Books.

-_- 2013. "The Metaphysics of Crackle: Afrofuturism and Hauntology”. Dancecult: Journal of Electronic Dance Music Culture (5)2: 41-55.

Gholz, Carleton. 2011. "Maintaining 'Synk' in Detroit: Two Case Studies in the Remix Aesthetic". Dancecult: Journal of Electronic Dance Music Culture (2) 1: 45-62.

Gibson, William. 1984. Neuromancer. New York: Ace Science Fiction.

Gikandi, Simon. 2006. "Picasso, Africa and the Schemata of Difference". In Beautiful Ugly: African and Diaspora Aesthetics, ed. Sarah Nuttall, 30-59. Durham: Duke University Press.

Gilroy, Paul. 1993. The Black Atlantic: Modernity and Double Consciousness. Cambridge: Harvard University Press.

- - - 2004. Between Camps: Nations, Cultures and the Allure of Race. London: Routledge.

Halpern, Richard. 1997. Shakespeare Among the Moderns: Towards a Mechanics of Modernist Fiction. Ithaca: Cornell University Press.

James, George G.M. 2001 [1954]. Stolen Legacy. Sauk Village: African American Images.

Jameson, Fredric. 1981. The Political Unconscious: Narrative as a Socially Symbolic Act. Ithaca: Cornell University Press.

Joseph, Anthony. 2006. The African Origins of UFOs. Cambridge: Salt Publishing.

Kreiss, Daniel. 2008. "Appropriating the Master's Tools: Sun Ra, the Black Panthers, and Black Consciousness, 1952-1973”. Black Music Research Journal 28(1): 57-81.

Labare, Sha. 2010. "Farfetchings: On and In the SF Mode." Ph.D dissertation (History of Consciousness), University of California at Santa Cruz.

Nelson, Alondra. 2002. "Introduction: Future Texts". Social Text (71): 1-15.

_- - Thuy Linh N. Tu and Alicia Headlam Hines, ed. 2001. Technicolor: Race,

Technology and Everyday Life. New York: New York University Press.

- - - and Paul D. Miller. 2004. "About Afrofuturism". Afrofuturism.net. < http://www. afrofuturism.net/text/about.html> (accessed 27 May 2004).

Nuttall, Sarah, ed. 2006. Beautiful Ugly: African and Diaspora Aesthetics. Durham: Duke University Press.

Pope, Richard. 2011. "Hooked on an Affect: Detroit techno and Dystopian Digital Culture". Dancecult: Journal of Electronic Dance Music Culture 2(1): 24-44.

Ra, Sun. 2005. Sun Ra: Collected Works Vol. 1, Immeasurable Equation. Ed. Adam Abraham. Chandler: Phaelos.

Ranta, Alan. 2013. "Jeff Mills, Hangar, Vancouver BC, September 12". Exclaim.ca. 13 September: <http://exclaim.ca/Reviews/NewForms/jeff_mills-hanger_vancouver_bc_september_12> (accessed 14 September 2013).

Rollefson, J. Griffiths. 2008. “The 'Robot Voodoo Power' Thesis: Afrofuturism and Anti-AntiEssentialism From Sun Ra to Kool Keith”. Black Music Research 28(1): 83-109.

Samuel, Lawrence R. 2007. The End of the Innocence: The 1964-1965 New York World's Fair. Syracuse: Syracuse University Press. 
Sinker, Mark. 1992. "Loving the Alien in Advance of the Landing-Black Science Fiction". WIRE (96). Szwed, John F. 1998. Space Is The Place: The Lives and Times of Sun Ra. New York: De Capo Press. van Veen, tobias c. 2003. "FUCK ART LET'S DANCE”. FUSE 26(3): 12-19.

-_- 2003a. "It's Not A Rave [2.0]". Graduate Researcher 1 (2): 90-96.

_- - 2013. "Afrofuturism Unbound: tobias c. van Veen in conversation with Paul D. Miller". Dancecult: Journal of Electronic Dance Music Culture (5)2.

Weheliye, Alexander G. 2005. Phonographies: Grooves in Sonic Afro-Modernity. Durham: Duke University Press.

Williams, Ben. 2001. "Black Secret Technology: Detroit Techno and the Information Age”. In Technicolor: Race, Technology, and Everyday Life, ed. Alondra Nelson and Thuy Linh N. Tu, 154-77. New York: New York University Press.

Womack, Ytasha. 2013. Afrofuturism: The World of Black Sci-Fi and Fantasy Culture. Chicago: Lawrence Hill Books.

Yaszek, Lisa. 2005. "An Afrofuturist Reading of Ralph Ellison's Invisible Man”. Rethinking History $9(2 / 3): 297-313$.

- - 2006. "Afrofuturism, Science Fiction, and the History of the Future". Socialism and Democracy 20(3): 41-60.

Yobie, Benjamin. 2010. “Texas approves renaming slave trade as 'Atlantic triangular trade”. SFGate.com. 21 May: <http://blog.sfgate.com/ybenjamin/2010/05/21/texas-approvesrenaming-slave-trade-as-atlantic-triangular-trade/> (accessed 21 September 2013).

Zuberi, Nabeel. 2004. "The Transmolecularization of [Black] Folk: Space Is the Place, Sun Ra, and Afrofuturism”. In Off the Planet: Music, Sound and Science Fiction Cinema, ed. Phillip Hayward, 77-95. Bloomington: Indiana University Press.

- _ - 2007. "Is This The Future? Black Music and Technology Discourse". Science Fiction Studies 34(2): 283-300.

\section{DISCOGRAPHY}

Burial. 2006. Burial. Hyperdub (UK): HDBC001 $<$ http://www.discogs.com/Burial-Burial/master/11767>.

Mills, Jeff. 1997. Kat Moda EP. Purpose Maker (US): PM-002 <http://www.discogs.com/Jeff-Mills-Kat-Moda-EP/release/236850>.

- - 2000. Metropolis. Tresor (DE): 155 <http://www.discogs.com/Jeff-Mills-Metropolis-2/master/255996>.

- - - 2009. Sleeper Wakes. Third Ear (JP): XECD-1122 <http://www.discogs.com/Jeff-Mills-Sleeper-Wakes/release/2049264>.

- - - 2013. The Jungle Planet. Axis (US): forthcoming.

Monáe, Janelle. 2008. Metropolis: The Chase Suite (Special Edition). Wondaland (US): 511234-2 $<$ http://www.discogs.com/Janelle-Monáe-Metropolis-The-Chase-Suite-Special-Edition/ release $/ 1507753>$.

- - . 2010. The ArchAndroid. Wondaland (US): 512256-2 <http://www.discogs.com/Janelle-Monáe-The-ArchAndroid/master/260095>. 
- - - 2013. The Electric Lady. Wondaland (US): 536210-2

<http://www.discogs.com/Janelle-Monáe-The-Electric-Lady/master/595570>.

Priest, Killah. 2013. The Psychic World Of Walter Reed. Proverbs Records (US):

<http://www.discogs.com/Killah-Priest-The-Psychic-World-Of-Walter-Reed/ release/4823265>.

Public Enemy. 1988. It Takes A Nation Of Millions To Hold Us Back. Def Jam (US): 527 358-1 $<\underline{\text { http://www.discogs.com/Public-Enemy-It-Takes-A-Nation-Of-Millions-To-Hold-Us-Back/ }}$ master/30296>.

Underground Resistance. 1998. Interstellar Fugitives. Underground Resistance (US): UR-045 < http://www.discogs.com/Underground-Resistance-Interstellar-Fugitives/master/783>.

X-102. 1992. X-102 Discovers The Rings Of Saturn. Tresor (DE): Tresor 4 <http://www.discogs.com/X-102-Discovers-The-Rings-Of-Saturn/master/4867>.

- - . 2008. X-102 Rediscovers The Rings Of Saturn. Tresor (DE): Tresor 234

<http://www.discogs.com/X-102-Rediscovers-The-Rings-Of-Saturn/release/1377125>.

FILMOGRAPHY

“Archandroid Janelle Monáe in Studio Q". 2011. YouTube. $<$ http://www.youtube.com/watch?v=KMxQEIGmDww > (accessed 21 September 2013).

“Janelle Monáe 'Dance or Die' Live 2011”. 2011. Youtube. <http://www.youtube.com/watch?v=CjqBSwkWM-c > (accessed 21 September 2013).

"Janelle Monáe - Many Moons [Official Short Film]". 2008. Youtube. <http://www.youtube.com/watch?v=LHgbzNHVg0c $>$ (accessed 01 January 2009).

"Janelle Monáe - Tightrope [feat. Big Boi] (Video)". 2010. Youtube.

<http://www.youtube.com/watch?v=pwnefUaKCbc > (accessed 01 January 2011).

"Jeff Mills presents The Messenger/Sleeperwakes - MUTEK 13 Edition - Montreal”. 2012. Youtube. <http://www.youtube.com/watch?v=Fb6NiTZB6Lc > (accessed 01 June 2013).

“Jeff Mills vs TR-909 LIVE @ MUTEK 2012". 2012. Youtube. <http://www.youtube.com/watch?v=06c-xOtPL7o > (accessed 01 June 2013).

Lang, Fritz. 1927. Metropolis. Germany: Universum Film (UFA). <http://www.imdb.com/title/tt0017136/>.

Lawrence, Francis. 2007. I Am Legend. USA: Warner Bros. <http://www.imdb.com/title/tt0480249/>.

Proyas, Alex. 1998. Dark City. USA: Mystery Clock and New Line Cinema. <http://www.imdb.com/title/tt0118929/>.

"Rolling Stone Presents Nas \& Janelle Monáe - Janelle Monáe Dances and ends off with Moon Walk". 2008. Youtube. <http://www.youtube.com/watch?v=hAmylsRHWGo> (accessed 01 January 2009).

Wachowski, Andy and Lana. 1999. The Matrix. USA: Warner Bros. <http://www.imdb.com/title/tt0133093/>. 